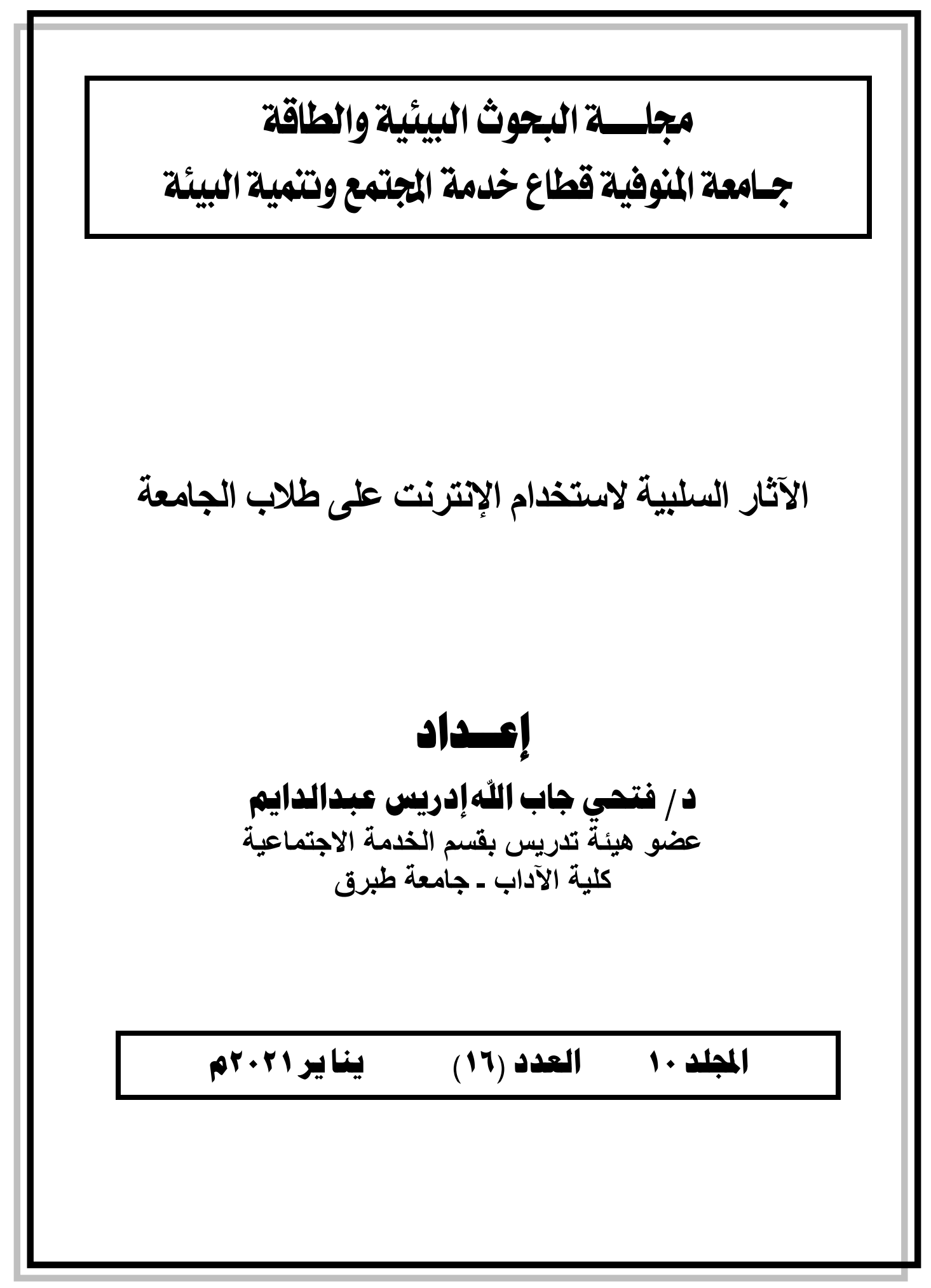


د/ فتحي جاب الله إدريس عبدالدايم

\section{الآثار السلبية لاستخدام الإنترنت على طلاب الجامعة}

\section{د/ فتحي جاب الله إدريس عبدالدايم}

عضو هيأة تدريس بقسم الخدمة الاجتماعية ـ كلية الآداب ـ جامعة طبرق

الملخص:

تكتسب البحوث والدراسات الاجتماعية - بثكل عام - أهميتها من الموضوع الذي تتناوله، وأثره في مسيرة المجتمع ، وبما أن هذه الدراسة أهتمت بموضوع الآثار السلبية لاستخدام الإنترنت على طلاب الجامعة فقد هدفت إلى التعرف على عادات استخدام الإنترنت اليومية من قبل الطلاب وكذلك الدوافع لاستخدام هذه الشبكة وأهم الآثار السلبية لاستخدامها، ولتحقيق هدف الدراسة أُعدت استبانة وجرى التحقق من صدقها وثباتها، وتكونت عينة الدراسة من \&1 ا طالباً وطالبة ممن يدرسون في كلية الآداب جامعة طبرق، وقد استخدم فيها "المنهج الوصفي"، باعتباره المنهج المناسب الذي يخدم طبيعة هذه الدراسة وأغراضها ويفي بمتطلباتها البحثية، وقد توصلت الدراسة إلى مجموعة نتائج كان من بينها أن أكثر الآثار السلبية للإنترنت على الجوانب التعليمية ضياع وقت مراجعة المحاضرات و قلة المشاركة في أثناء المحاضرات و تراجع المستوي الدراسي لدى عينة، ومن أهم النتائج التي توصلت إليها النتائج قلة الوقت الذى يقضى مع الاسرة و تجنب الزيارات العائلية تُعد من أكثر الآثار السلبية للإنترنت على العلاقات الأسرية، كما أن أكثر الآثار السلبية اجتماعياً

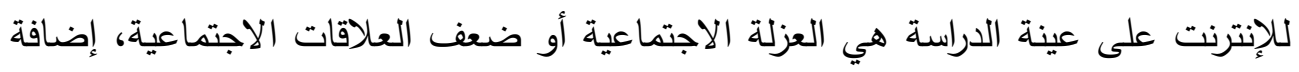
إلى أنه يسبب قلة ساعات النوم و آلام في الظهر والرقبة و ضعف النظر أكثر الآثار السلبية للإنترنت على الصحة لاى عينة الدراسة.

مقدمة:

شهدت نهايات القرن العشرين وبدايات القرن الحادي والعشرين انفجاراً معرفياً ، وتطوراً متسارعاً في تقنية المعلومات والاتصالات، أدى إلى تغيرات جذرية في مناحي الحياة 


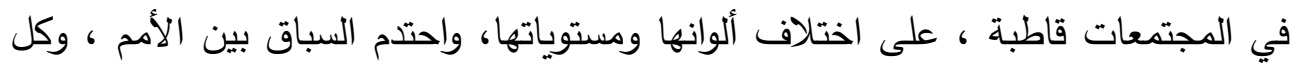

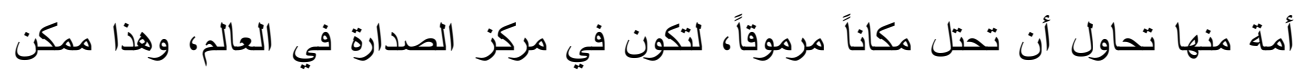

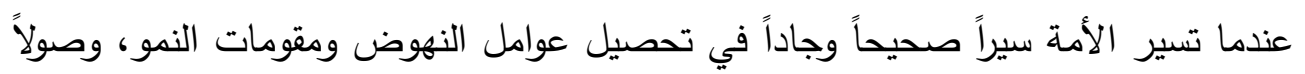

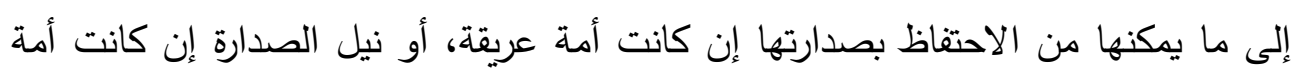

ونتيجة الاعتماد المتزايد على شبكة الإنترنت في مجال الاتصال، اهتم الباحثون في

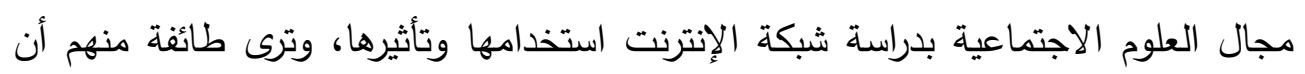
شبكة الإنترنت تشكل بحق ثورة معلوماتية واتصالية، وذلك من خلال تقديمها شكلاً جديداً من أشكال التواصل البشري. (')

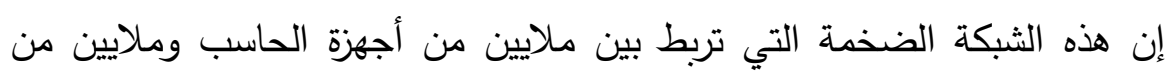

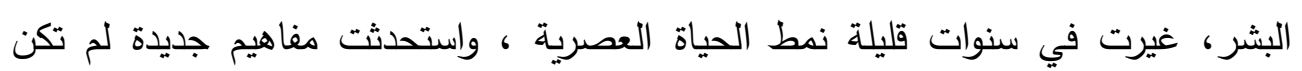

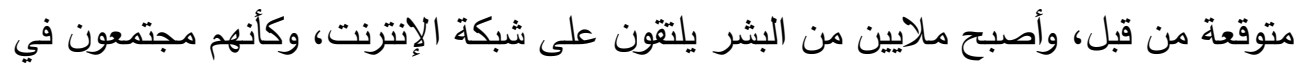

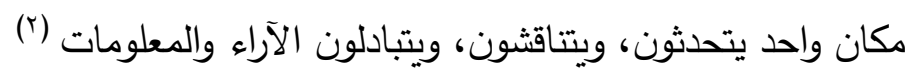

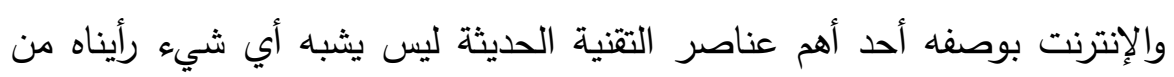

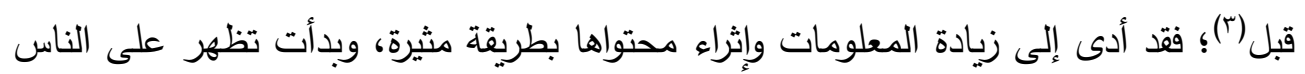

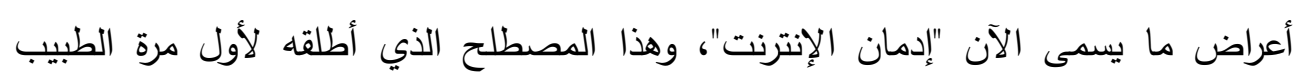

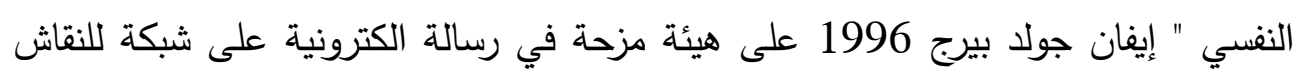

$$
\text { "الدردشة" عبر الإنترنت. }
$$

لقد بات سوء استخدام الإنترنت امراً واقعاً لا مجال لتجاهله، وكما أن لثبكة الإترنة

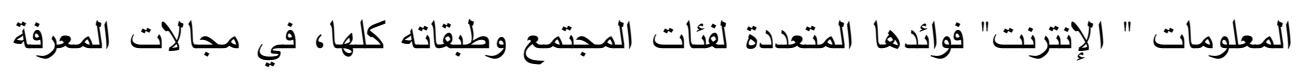

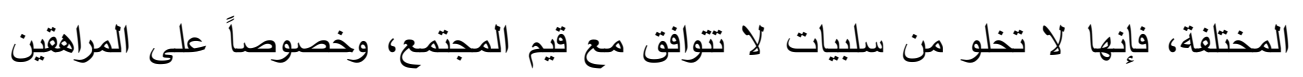

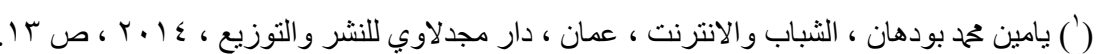

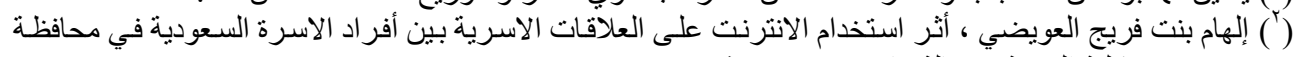

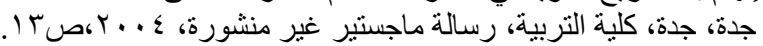

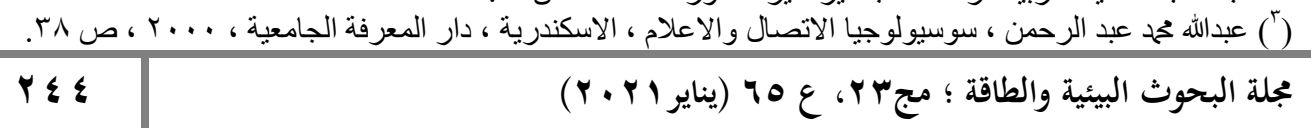


د/ فتحي جاب الله إدريس عبدالدايم

والثباب كإدمان التواصل إلكترونياً مع الآخرين خصوصاً من الجنس الآخر المستخدم للإنترنت. (') (1)

ومن السلبيات المرتبطة بالإنترنت إهدار الوقت، وإهمال الالتزامات والأنشطة الاجتماعية ، وتدني المستوى الدراسي ، وفقدان العمل، وتدهور العلاقات الاجتماعية،

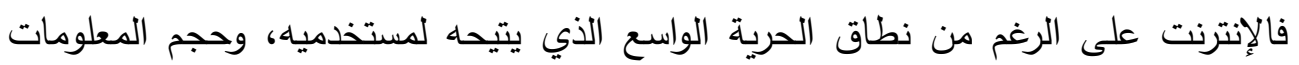

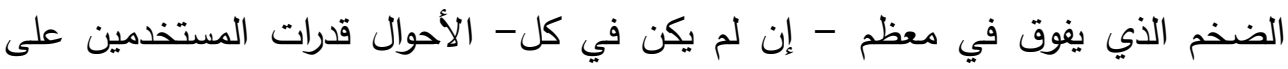

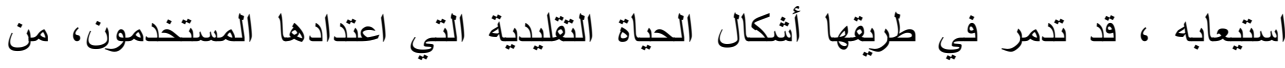

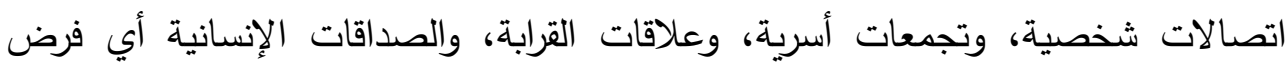

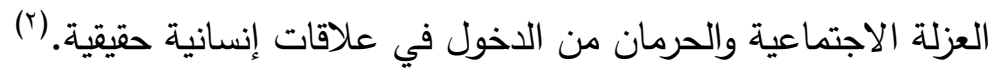
وقد تطغى النواحي السلبية للإنترنت على النواحي الايجابية؛ فمن يسيئون استخدام

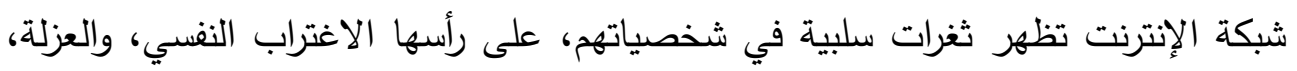
وانخفاض مهارات التواصل، والانحراف، والتعرض لبعض المشكلات التي تبدو في صورة توتز وقلق وصراعات داخلية.

وعندما يفرط الإنسان في استخدام شبكة الانترنت من حيث المدة أو نوعية

الاستخدام وأغراضه أو تطبيقاته يجد نفسه مدفوعاً بشكل قسري - دون حاجة فعلية ملحة -

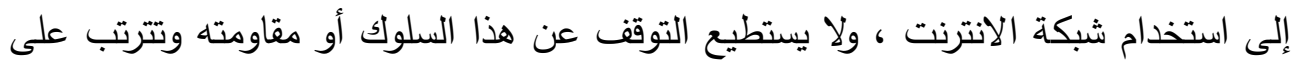

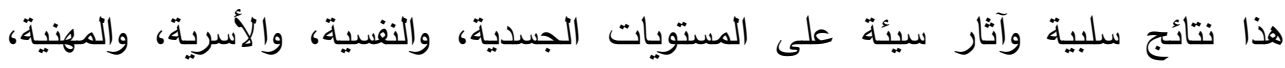

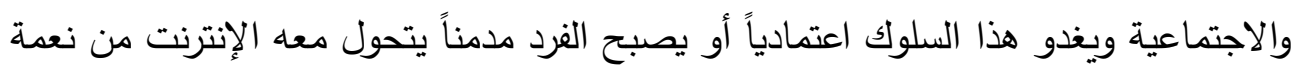
إلى نقهة. (r)

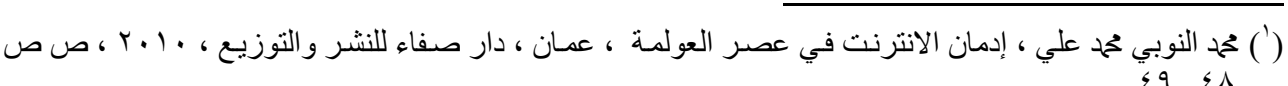

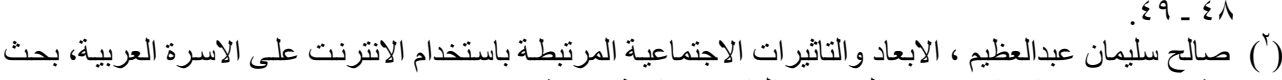

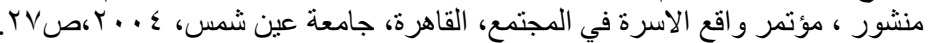

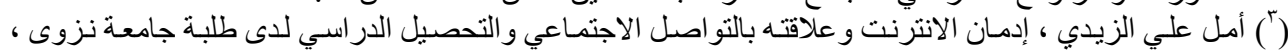

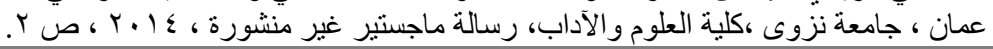


وقد يستخدم الشباب تلك الشبكة بحرية غير منضبطة ودونما رقابة من أولياء الأمور، فيمارسون عدداً من السلوكيات السلبية مثل التجسس على خصوصيات الآخرين عبر الثبكة ، وعندما يجلسون أمام الحاسوب لساعات طويلة تقودهم الثبكة غالباً من موقع

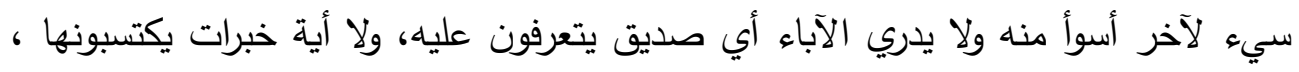
كما أن شبكة الإنترنت أتاحت لهح العديد من المعلومات والصور والمواقع الإباحية، فأصبحت سهلة مباحة لكل فرد. (')

وبطبيعة الحال فإن طلاب المرحلة الجامعية من أثد الفئات ولعاً بهذه التقنية ، أنهات لاسيما وقد أصبح في متتاول الطالب العادي ذي الامكانات المتواضعة العديد من أدوات العصر الحديث، كالهاتف النقال والحاسوب والبث المباشر ، وتلك الأدوات تؤثر في حياته بصورة مباشرة، بما تحمل من أفكار ليس في مقدوره التعامل معها بسهولة نظراً لطبيعة

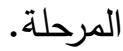

\section{مشكلة الدراسة:}

لقد تأثرت فئة الشباب بانتشار شبكات الانترنت، حيث اصبحوا عن طريقه يتواصلوا مع أقرانهم، ويكونوا صداقات وعلاقات عاطفية. أكدت ذلك دراسة حلمي وعبدالباقي ال ..

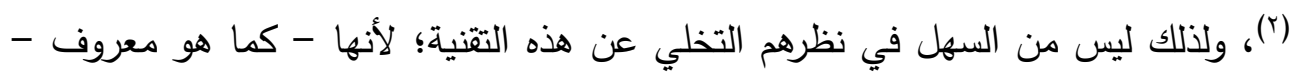
تلعب أدواراً إيجابية وأخرى سلبية، والإيجابية يجب تعزيزها، والسلبية يجب معالجتها، عبر هـره وضع استراتيجيات للتقليل من آثارها السلبية.

هذا الارتباط القوي بالإنترنت يصل بالطالب مرحلة الإدمان عليه، حتى يؤدي به إلى تجاهل الأنشطة والمناسبات، والدراسة من باب أولى. وقد بينت دراسة عادل المغذوي

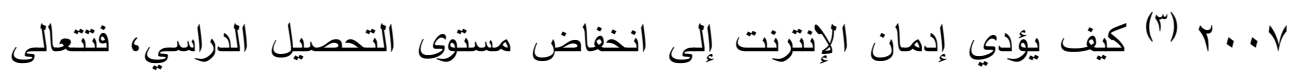

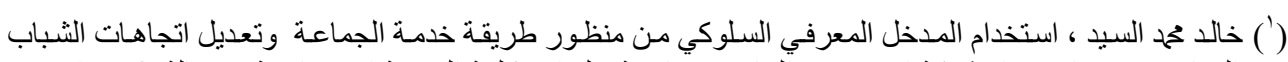

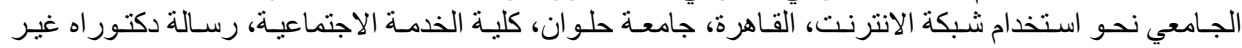

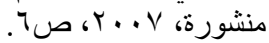

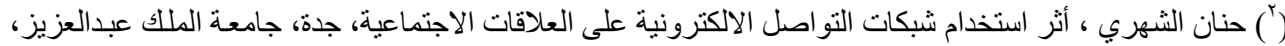

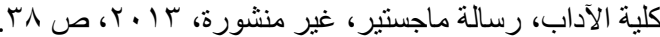

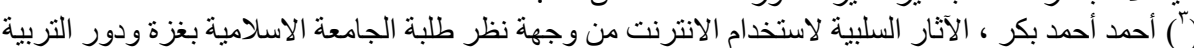

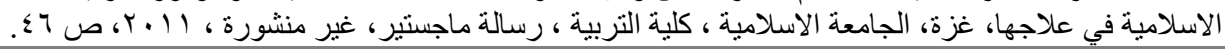


شكوى المقربين من الطالب من قضائه اوقاتاً مديدة أمام الإنترنت. ويغدو من المستحيل

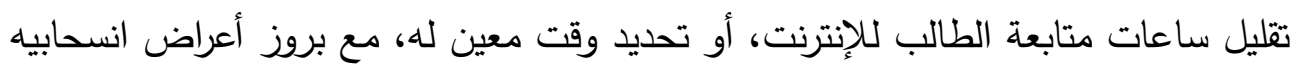

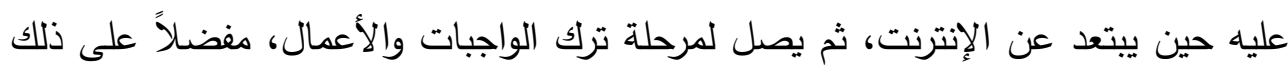

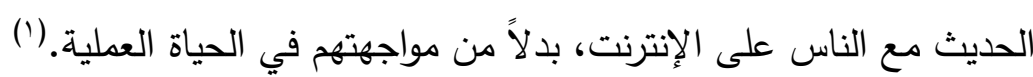
ومما يسّر استخدام تكنولوجيا الإنترنت، شيوع الهواتف النقالة، خاصة الذكية منها، في أيدي الطلاب، وبغض النظر عن مستوى ثقافتهم ودرجة تعلمهم، فإن استعماله سهل

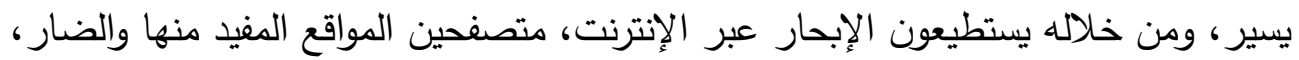

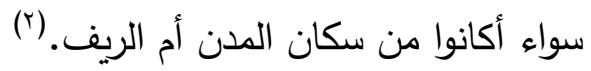

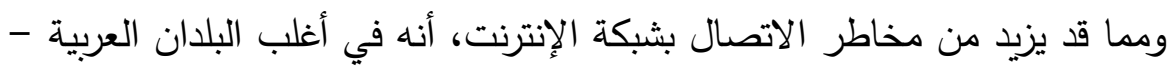

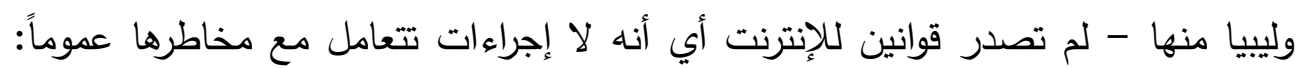
الاجتماعية والنفسية والأخلاقية. وهناك تسليم بأنه لا يمكن السيطرة على الانترنت بقوانين التانين

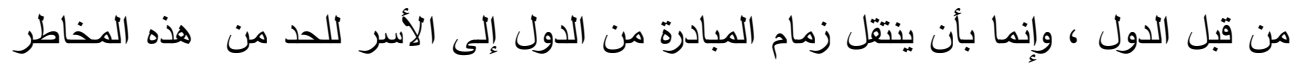

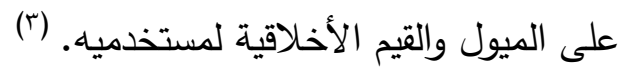

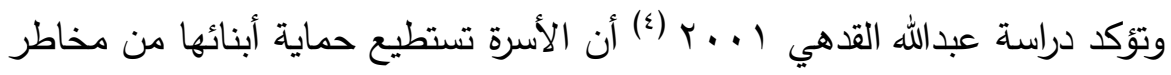
الإنترنت إذا ما كانت هناك متابعة لهم، وللمواقع التي يطلعون عليها. وتؤكد دراسة أجراها برينر أن الإنترنت يؤدي إلى تفكك العلاقات الأسرية والاجتماعية، وأن علاقات الأفراد الإداد

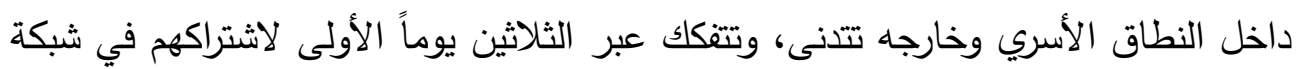
الإنترنت؛ فلا يعود هناك اجتماع حول مائدة الطعام، وتغيب النزهة الجماعية ، كما أن النالني إدمان الإنترنت يؤدي إلى إهدار الوقت، ومن ثم إهمال الأنثطة الدراسية والأسرية والاجتماعية. وتؤكد دراسة بيلالك 1997 إلعلى أن من بين ألف مشترك في الإنترنت يعاني

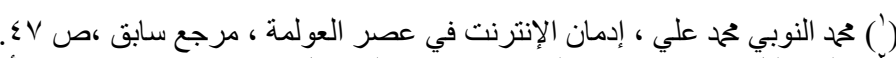

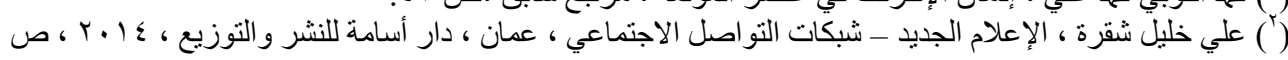

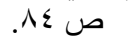

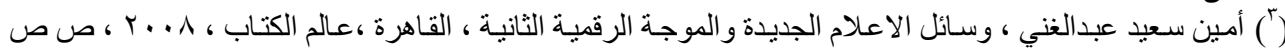
$.111-11$. ( ) أحمد أحمد بكر ، الآثار السلبية لاستخدام الانترنت مـن وجهـة نظـر طلبـة الجامعـة الاسـلامية بغزة ودور التربيـة

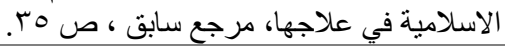


ما يقرب من مائتين من أعراض إدمانية خطيرة للإنترنت، تتسبب في الفشل الدراسي أو تفكك

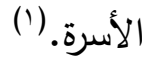

أهمية الدراسةة: - الاسرة:

1- تتجلى أهمية هذه الدراسة في أنها قد تسهم في إثراء الأدبيات السوسيولوجية حول ظاهرة استخدام شبكة الإنترنت التي هي إحدى وسائل التقنية الحديثة، التي تزايد عدد مستخدميها في السنوات الأخيرة بشكل واضح ، واتسع نطاق تأثيرها في ثقافة الأفراد واتجاهاتهم. r ـ تتضح أهمية هذه الدراسة من أهمية الفئة المستهدفة، وهي طلاب الجامعة وهم في مرحلة عمرية حساسة جداً، وتحتاج إلى رعاية ومتابعة؛ إذ تتكون الهوية والثخصية في هذه الفترة.

r. الظاهرة محل الدراسة من الموضوعات الجديدة في المجتمع الليبي بشكل عام، والمدينة محل الدراسة بشكل خاص، ومن ثم من المهم رصد التغيرات كافة والمشكلات الناتجة عنها. ه. قد تساعد الدراسة المتخصصين في المجالات النفسية والاجتماعية على بناء برامج وقائية للحد من آثار الإنترنت السلبية.

\section{أهداف الدراسة:}

1 - - تحديد عادات طلاب الجامعة وأنماط استخدامهم الإنترنت.

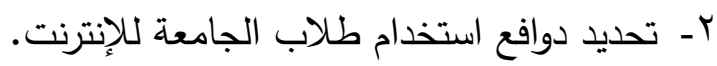
r- تحديد الآثار السلبية المترتبة على استخدام شبكة الإنترنت. تساؤلات الاراسة:

وفي ضوء ما طرحه الباحث من أفكار حول مشكلة الدراسة، والأبعاد المختلفة التي تشكل الإطار العام لها ، وفي إطار الأهداف التي تسعى إليها، يسعى الباحث للإجابة العلمية عن التساؤلات الآتية:

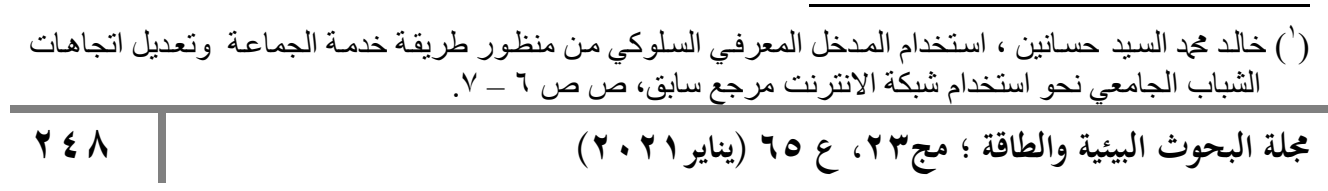


د/ فتحي جاب الله إدريس عبدالدايم

$$
\begin{aligned}
& \text { 1- ما عادات طلاب الجامعة وأنماط استخدامهم الإنترنت؟ } \\
& \text { r- ما دوافع استخدام طلاب الجامعة للإنترنت ؟ } \\
& \text { ب- ما الآثار السلبية للإنترنت ؟ } \\
& \text { مصطلحات الاراسة: } \\
& \text { الآثار السلبية: - ماتية }
\end{aligned}
$$

الأثر بقية الثيء، وجمعه آثار وأثقر ، والآثار السلبية هي النتائج المترتبة على

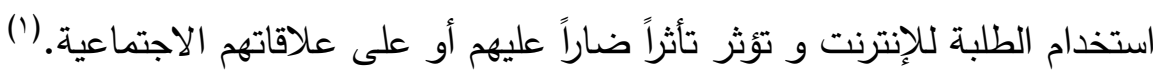

الإنترنت مجموعة من شبكات المعلومات الدولية، التي تترابط بشكل يتيح تبادل

$$
\text { المعلومات بين البشر على اتساع العالم كله. (r) }
$$

أو هو بتعريف بسيط شبكة عالمية غير مملوكة لدولة بعينها، تربط آلاف الثبكات ومئات الملايين من أجهزة الحاسوب مختلفة الأنظمة والأنواع والأحجام في العالم، وفق معايير اتصالات معينة، وهي أهم وسيلة معاصرة للتواصل وتبادل المعلومات بين الأفراد والمؤسسات. (r) ويقصد الباحث بالإنترنت في هذه الدراسة: شبكة عالمية يتواصل من خلالها

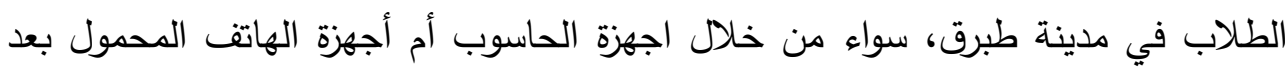
ربطها بشبكة الإنترنت؛ بغرض التواصل الاجتماعي أو الحصول على المعرفة في المجالات العلمية المختلفة، ولها آثارها السلبية على طلاب المرحلة الجامعية. سوء استخدام الإنترنت: ويقصد به أن مستخدم الإنترنت يفقد الإحساس بالجوانب الأخلاقية والدينية عند استخدامه لهذه التقنية، ولا يقترن استخدامه للإنترنت عنده إلا بما يحققه من إشباع لغرائزه، (') احمد بكر ، قنيطة، الآثار السلبية لاستخدام الانترنت من وجهة نظر طلبة الجامعة الاسلامية بغزة ودور التربيـة

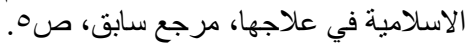

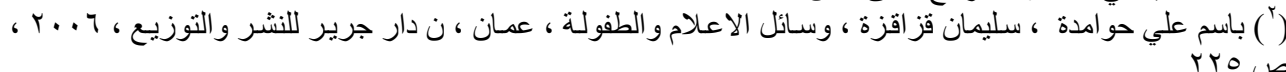

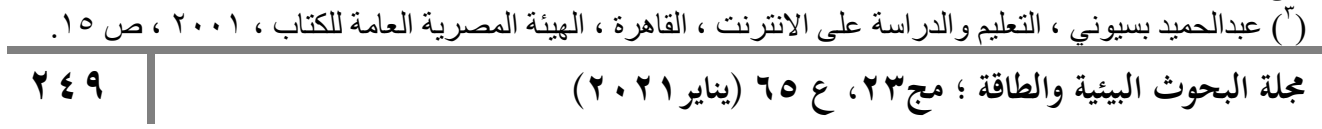


دونما إدراك منه بما يسببه هذا الاستخدام السيء من ممارسات شاذة أو غير أخلاقية، أو توقعه تحت طائلة القانون. (') ويعرف شبيرا وآخرون . . . سوه استخدام الإنترنت بأنه: فقدان السيطرة أو التحكم

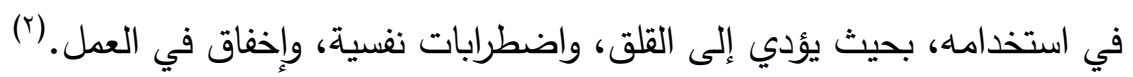

$$
\text { الاراسات السابقة: }
$$

ا - دراسة جهاد علاءالاين ـ ا ـ ץ: بعنوان"|لنتائج السلبية لاستخدام الإنترنت": وكان هدفها الرئيس فحص صدق فرضيات النموذج المعرفي السلوكي لاستخدام الإنترنت الإشكالي، حول علاقة التفضيلِ للتفاعل الاجتماعي على الإنترنت بمتغيرات الوحد ة والاكتئاب، والأعراض الأخرى في هذا الحقل ودور هذه المتغيرات في مفاقمة النتائج السلبية لاستخدام الإنترنت ، وأثشارت النتائج إلى أن النموذج المعرفي السلوكي كان ملائماً للبيانات

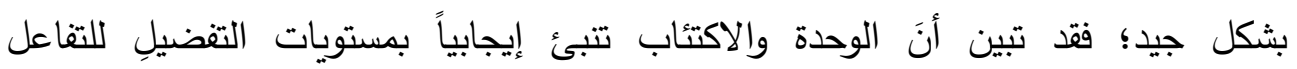
الاجتماعي على الإنترنت ، بالإضافة إلى ذلك أظهرت النَتائج أن متغيّرات استخدام

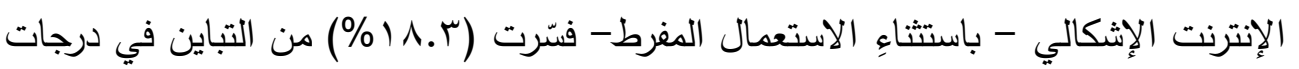
المشاركين، على مقياس النتائج السلبية المترتبة على استخدام الإنترنت ، في حين أسهمت الإنتان

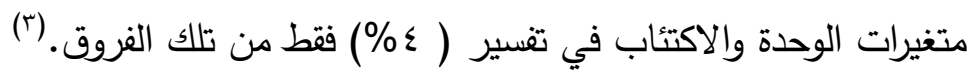
r - دراسة أمل الزيدي ؟ 1 ـ ؟ وعنوإنها: "إدمان الإنترنت وعلاقته بالتواصل الاجتماعي

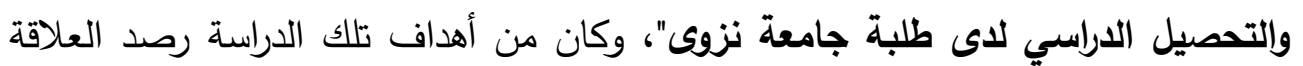

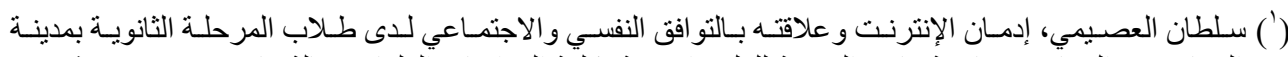

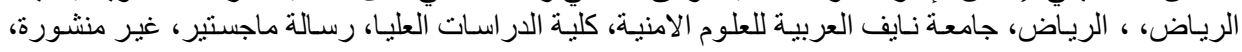

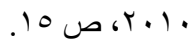

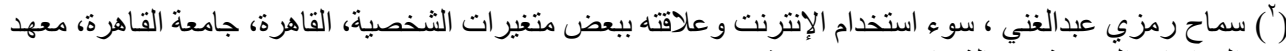

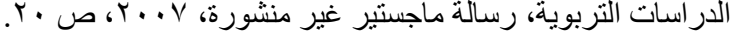

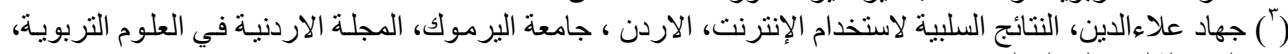

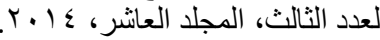


بين إدمان الإنترنت وكل من التواصل الاجتماعي والتحصيل الدراسي، لدى طلبة جامعة نزوى، وتكونت العينة من ب إء طالباً وطالبة، وأظهرت نتائجها بلوغ عدد مدمني ولإني استخدام

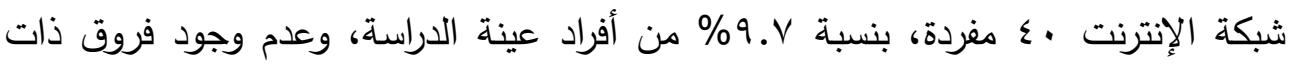
دلالة إحصائية بين المتوسطات الحسابية لمقياس إدمان الإنترنت تعزي لمتغير النوع الاجتماعي، والمستوى الدراسي وكذلك وجود علاقة عكسية ذات دلالة إحصائية بين إدمان الإنترنت والتواصل الاجتماعي ، ووجود علاقة ضعيفة ذات دلالة إحصائية بين ذلك الإدمان

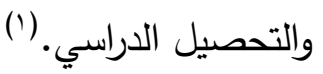
ץ- دراسة ناجية مصطفى صالح ب ا ـ ץ: وعنوانها "تأثير استخدام الإنترنت على الثباب الجامعي بالمجتمع الليبي" وكان هدفها الوقوف على طبيعة العلاقات التي يبنيها الثباب عبر الإنترنت، ومدى تأثيرها على العلاقات الأسرية والاجتماعية في الواقع. وطبقت الدراسة

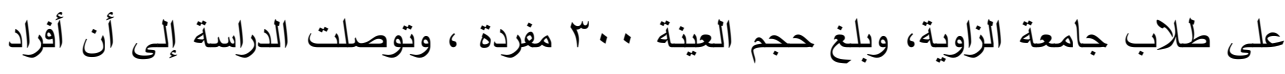
العينة يفيدون من الإنترنت في المجال الأكاديمي ، كما أكدوا أن للإنترنت دوراً ايجابياً في

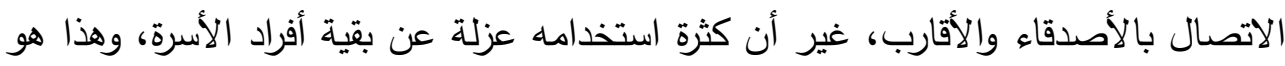

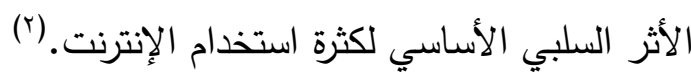

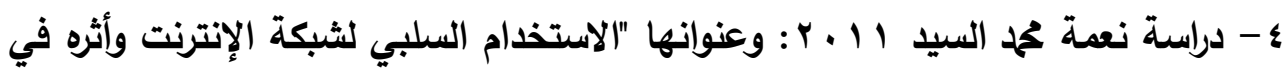

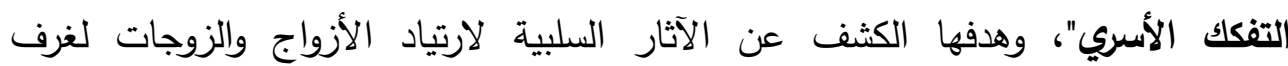

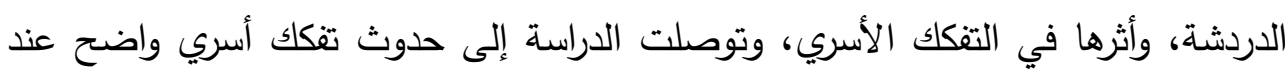

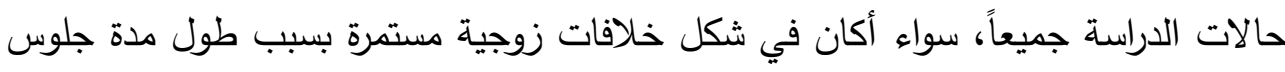
الزوج أو الزوجة أمام شبكة الإنترنت لفترات طويلة ، وأم إدمان المواقع الإباحية مما أثر لثراه بالسلب على علاقاتهم بزوجاتهم. (r) 
الآثار السلبية لاستخدام الإنترنت على طلاب الجامعة

ه- دراسة أحمد بكر قنيطة 11 ـ ب: وعنوانها "الآثار السلبية لاستخدام الإنترنت من

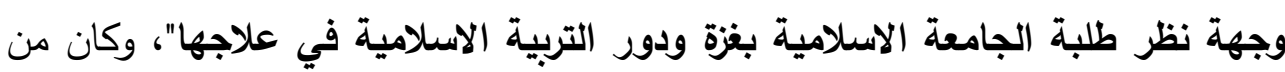
أهداف تلك الدراسة معرفة الفروق بين متوسطات درجات تقدير الطلبة للآثار السلبية لاستخدام الإنترنت، في ضوء متغيرات الدراسة: (الجنس، والتخصص، والمعدل، وعدد ساعات استخدام الإنترنت أسبوعياً). واتبع الباحث المنهج الوصفي التحليلي، وتكونت عينة

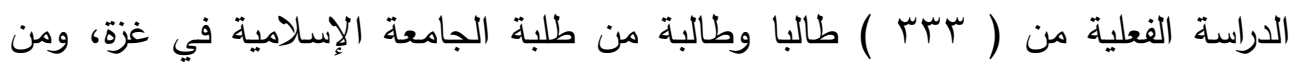
تخصصات (التربية، الشريعة، الهندسة)، وتوصلت الدراسة إلى أن نسبة الآثار السلبية

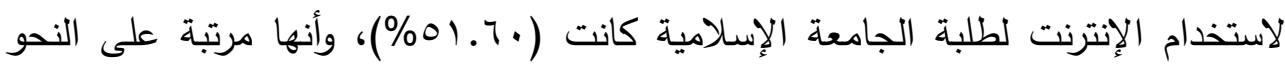

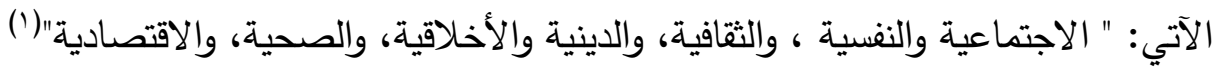

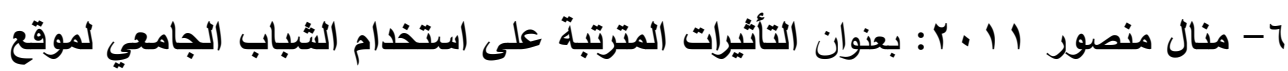
الفيس بوك وكان هدفها التعرف على دوافع مشاركة الثباب في الحملات التي ينظمها الموقع ، وأهم تلك الحملات الإعلامية التي يشارك الثباب فيها عبره. واعتمدت الدراسة على

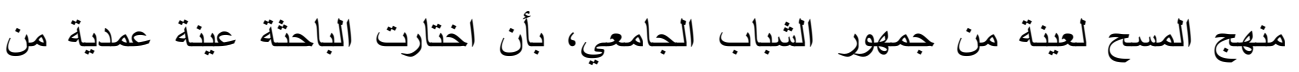

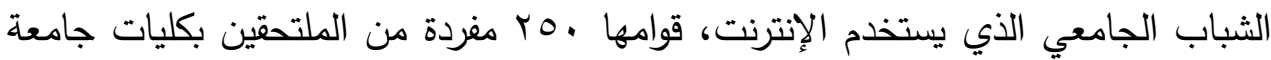
قناة السويس بمحافظة بورسعيد ، واعتمدت على استمارة استبيان أداةً لجمع البيانات. ومن لهن أهم النتائج التي توصلت إليها الدراسة، أن جاءت المواقع الاجتماعية في المركز الأول

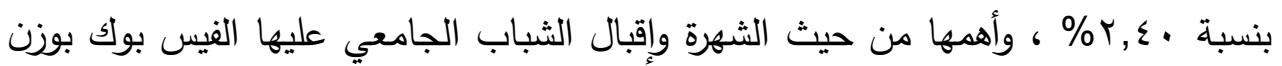
نسبي ع.r \% ، ، يليه في المركز الثاني موقع تويتر، بوزن نسبي قدره r.r\% ، وكانت حملات الترويج عن السلع المصرية أهم الحملات التي شارك فيها الثباب المصري ، بنسبة بلية ا.rr\% ، أما عن أسباب تفضيل الثباب المواقع الاجتماعية فتمثلت في التواصل مع

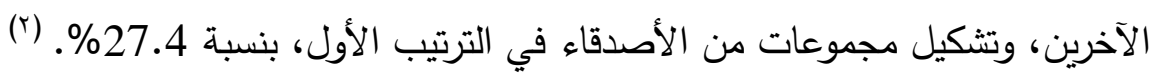

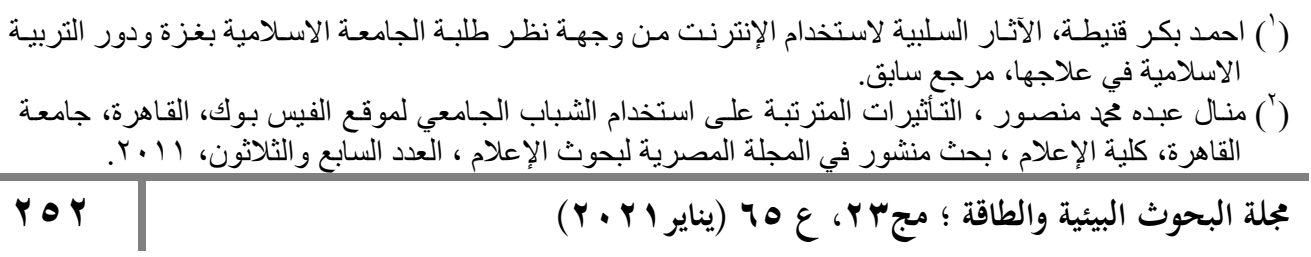


د/ فتحي جاب الله إدريس عبدالدايم

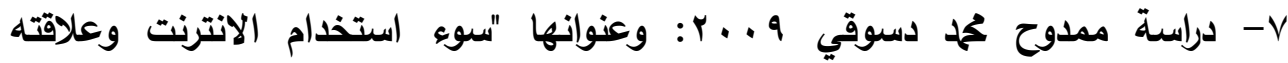
بمشكلات طلاب الجامعة"، وطبقت تلك الدراسة على طلاب جامعة كفر الثيخ، وبلغ حجم

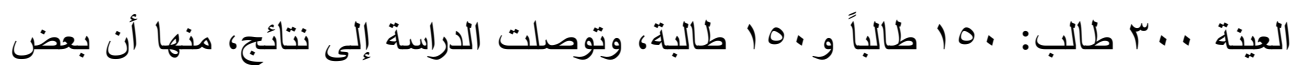
أفراد العينة لا يستطيعون الاستغناء عن الإنترنت وإقامة علاقات مع الجنس الآخر، بالإضافة إلى فقدان الصلة مع المحيط الاجتماعي الذي يعيشون فيه و الشعور

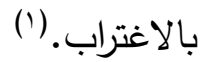

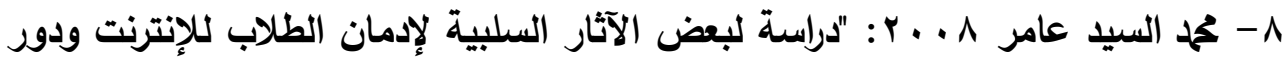
الخدمة الاجتماعية في التخفيف من حدتها"، وهدفت الدراسة إلى الوقوف على أسباب إدمان طلاب المرحلة الثانوية للإنترنت، وأهم الآثار السلبية لإدمان الإنترنت على الطالب،

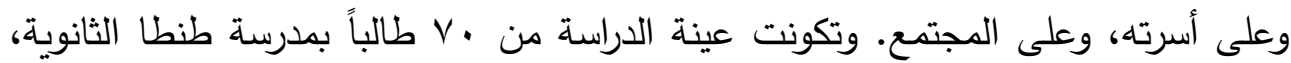

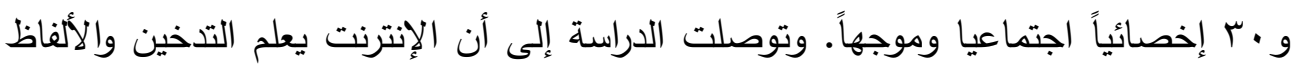
البذيئة، والهروب من المدرسة، والرجوع إلى المنزل في وقت متأخر، والانعزال عن الأسرة،

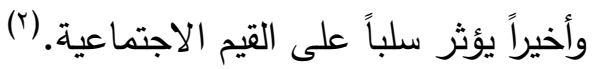
الاراسات الاجنبية:

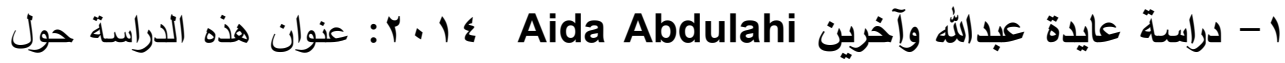
"الآثار السلبية لمواقع الثبكات الاجتماعية مثل الفيس بوك"، وطبقت على طلاب إحدى الجامعات الماليزية؛ للتعرف على الآثار السلبية للاتصالات الالكترونية على الإسى حياتهم، وخاصة الأداء الأكاديمي. وأوضحت نتائج الدراسة أن لشبكات التواصل الاجتماعي التسي

(') ممدوح محمد دسوقي، سوء استخدام الانترنت و علاقته بمشكلات طلاب الجامعة، القاهرة، جامعة حلوان، المؤتمر

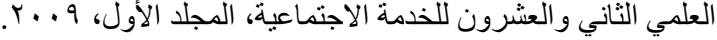

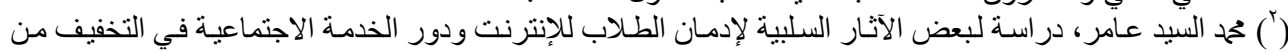

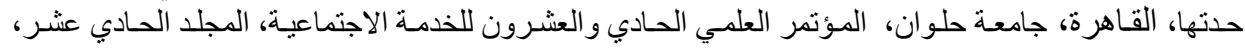

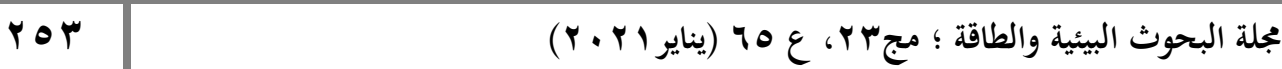


آثاراً سلبية عدة، أبرزها الآثار الصحية، لاستخدامهم الانترنت لساعات طويلة كل يوم ، كما بينت الدراسة أن هناك إدماناً من الطلاب لاستخدام الإنترنت.

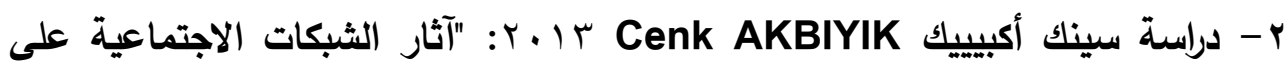
الحياة الاجتماعية لطلبة المرحلة الجامعية" ، لاسيما الطلاب الجدد، وطلاب الفرقة الثانية في الجامعة. وجمعت البيانات عن طريق المقابلة ، وأظهرت نتائج الدراسة أن بعض الابه الطلاب لا يرون لشبكات التواصل الاجتماعية أثراً على الإطلاق في حين ذهب آخرون إلى ولى

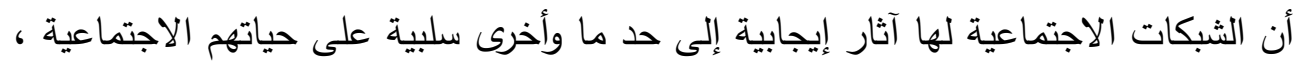
وكان الأثر الايجابي المذكور الإبقاء على التواصل مع الأصدقاء، أما الأثر السلبي

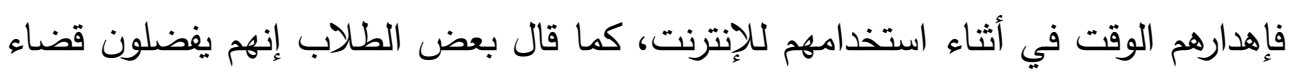

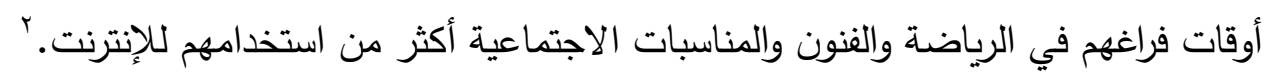

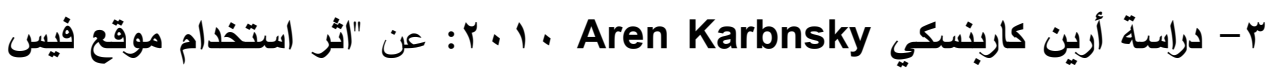
بوك على التحصيل الدراسي لاى طلبة الجامعات" وطبقت تلك الدراسة على 9 اب طالباً جامعياً ، وأظهرت نتائجها أن الدرجات التي يحصل عليها طلاب الجامعات المدمنون للإنترنت وتصفح موقع "فيس بوك" كبرى الثبكات الاجتماعية على الإنترنت أدني بكثير من تلك التي يحصل عليها نظراؤهم الذين لا يستخدمون هذا الموقع. كما أظهرت النتائج أنه كلما ازداد الوقت الذي يمضيه الطالب الجامعي في تصفح هذا الموقع تدنت درجاته في الامتحانات، ومن يقضون وقتاً أطول على الإنترنت يخصصون وقتا أقصر للدراسة، مشيراً إلى أن لكل جيل اهتماماته، وأن هذا الموقع يتيح للمستخدم "الدردشة" وحل الأحاجي، وإبداء

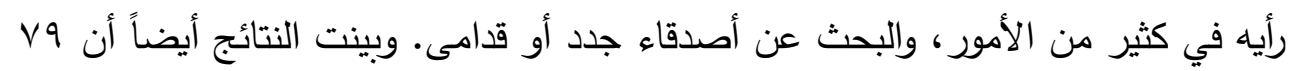

- . Aida Abdulahi, A Study on the Negative Effects of Social Networking Sites Such as Facebook among Asia Pacific, International Journal of Business and Social Science, University of Technology and Innovation Technology Park Malaysia, 2014, p 133.

$\checkmark$ - . Cenk AKBIYIK, Effects of Social Networks on Social Life of Undergraduate Students, Middle Eastern \& African Journal of Educational Research, Issue 6, Erciyes University Faculty of Education, Kayseri Turkey, 2013, p 5. 
د/ فتحي جاب الله إدريس عبدالدايم

\% من الطلاب الجامعيين الذين شملتهم الدراسة أقروا بأن إدمانهم لموقع الفيس بوك أثر

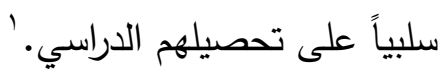
צ- دراسة كريستوس فرانجوس Christos C. Frangos 9 9. .ب: وكان عنوانها "إدمان الثباب على الإنترنت"، وهدفت إلى التعرف على نسبة إدمان طلاب الجامعة

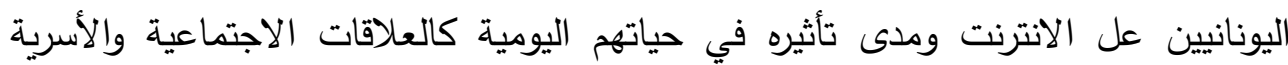

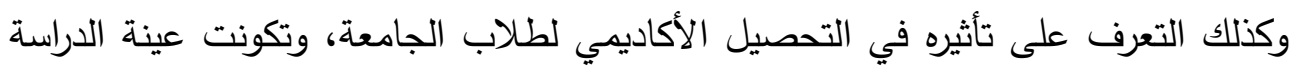

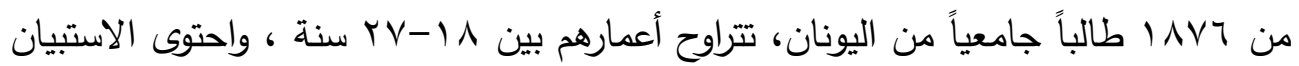

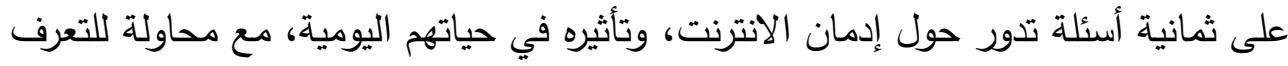

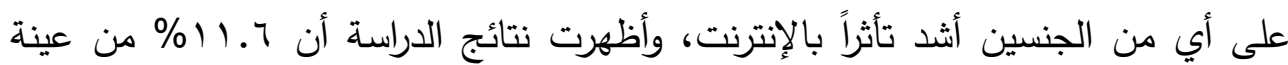

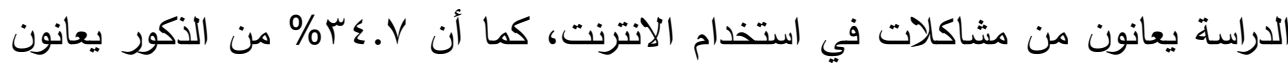

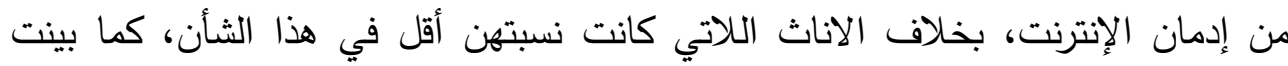

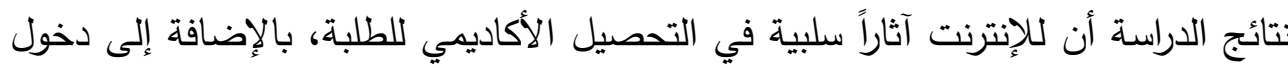

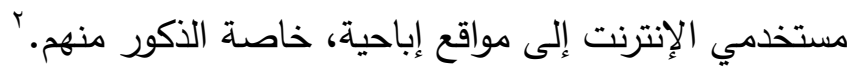

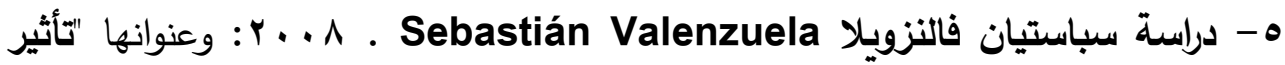

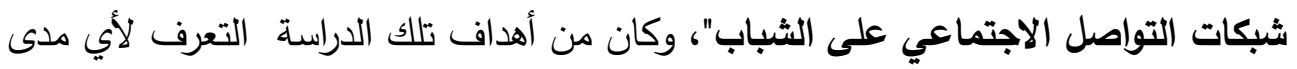

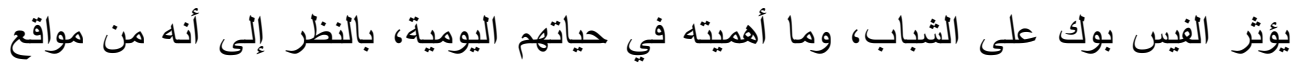

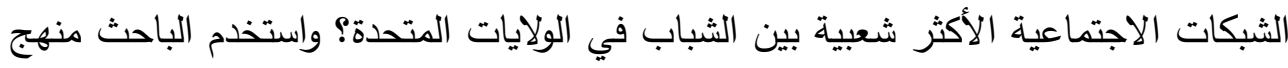

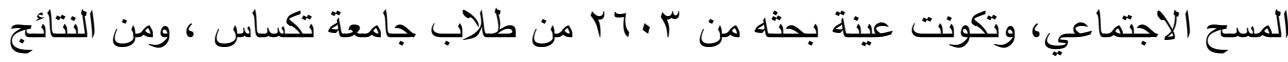
التي توصلت إليها الدراسة أن هناك علاقات إيجابية معتدلة بين كثافة استخدام الفيس بوك

- Aren, Karbiniski," Face book and the technology revolution", N,Y Spectrum publications 1, 2010.

${ }^{3}$ - Christos C. Frangos, Internet Addiction among Greek University Students, International Journal of Economic Sciences and Applied Research, University College London, London, UK, 2009, pp 49-74.

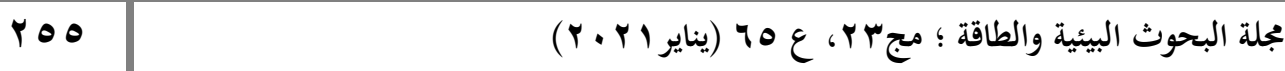


والرضا عن الحياة لاى الطلاب ، كما أظهرت النتائج نوعاً من إسهام شبكات التواصل في تدعيم المشاركة الاجتماعية والسياسية لدى الثباب.' ولياه

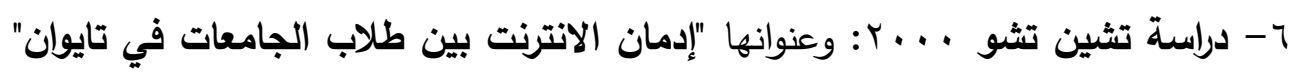
وطبقت الدراسة على اثثتي عشرة جامعة حكومية في تايوان، وأشارت نتائجها إلى أن إدمان الإنترنت موجود بين طلاب الجامعات هناك، وأن مدمني الإنترنت يقضون من الساعات

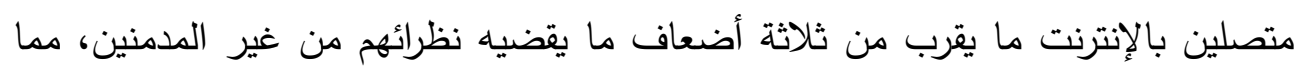

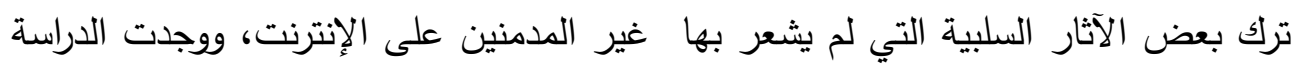

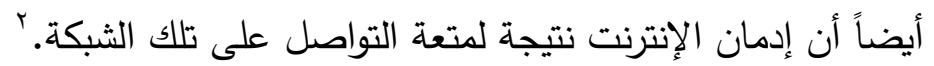
التعربف بالإنترنت:

كلمة Internet اختصار لكلمتين في اللُغة الانجليزية، هما: International و Networks ومعناهما الحرفي: شبكة الأعمال العالمية لكن اندماج الكلمتين أكسبهما المعنى المراد، وهو: شبكة المعلومات العالمية. ويتم من خلال الانترنت ربط مجموعة شبكات بعضها مع بعض في عدد من الدول، عن طريق خطوط الهاتف والأقمار الصناعية، بحيث

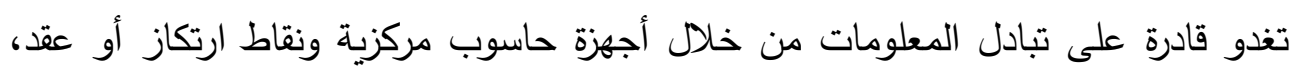
فيما يعتمد العمود الفقري للإنترنت على خطوط اتصالات تنقل البيانات بسرعة عالية، وتربط العقد وأجهزة الحاسوب المضيفة الرئيسة، وعبر هذه الخطوط تتحرك البيانات بكميات كبيرة وحزم متتابعة. (r) وللخبراء والعلماء العاملين في مجال الاتصالات والمعلومات والحواسيب والإعلام تعريفات عدة لشبكة الإنترنت، من منطلق طبيعة تعاملهم مع الشبكة ومجالات تدارسهم واستخدامهم لها. وفيما يلي بعض التعريفات:

' - . Sebastián Valenzuela, The Effect of Social Network Sites on College Students, University of Texas at Austin, International Symposium on Online Journalism, 2008, p2.

2 - Chien Chou, Internet addiction, usage, grati cation, and pleasure experience: the Taiwan college students' case, National Chiao Tung University, Taiwan, 2000, p 65.

(") مؤمن أحمد، أمن الإنترنت.. الدخاطر والتحديات، دولة الأهـارات العربية المتحدة، مكتب نائب رئيس الوزراء

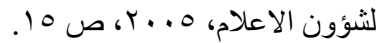


لُغةً تعني كلمة إنترنت (Internet): الترابط بين الثبكات، وهو جزء من ثورة

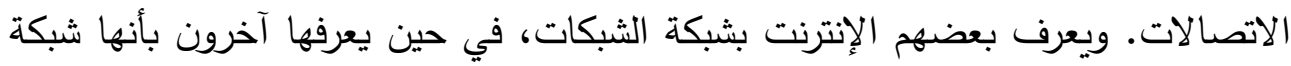

طرق المواصلات السريعة.(1)

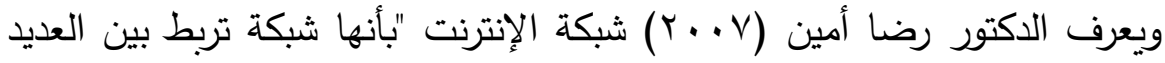
من الثبكات المنتشرة في العالم كله، من شبكات حكومية، وشبكات جامعات، ومراكز بحوث وشبكات تجارية، وخدمات فورية، ونشرات إلكترونية، وغيرها. يصل إليها أي شخص لائات الدايه

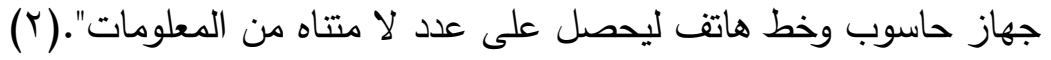
ويعرف دانيال ديرن Danniel, D., الإنترنت بأنها شبكة الاتصالات 1994

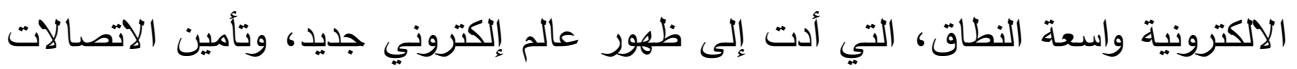

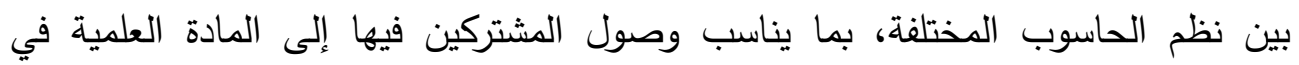

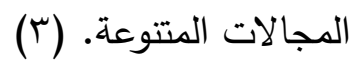
الحاجات التي يثبعها الإنترنت للطلاب: 1- الحاجات المعرفية: وهي الحاجات المرتبطة بتقوية المعلومات والمعرفة وفهم البيئة،

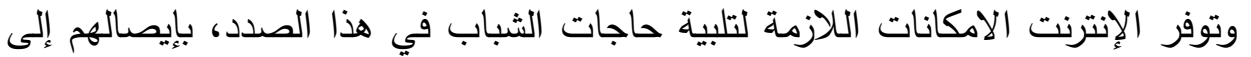
المواقع الأكاديمية، ومواقع تحميل الكتب الإكترونية، إضافة إلى مواقع طبية وإعلامية الكاتية

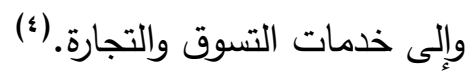

r- حاجات عاطفية: الإنترنت يضم مئات من المواقع لمختلف أنواع النشاط الترفيهي،

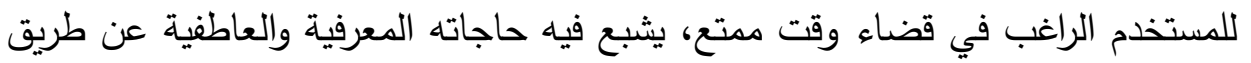

التصفح واكتثاف عوالم جديدة.(0)

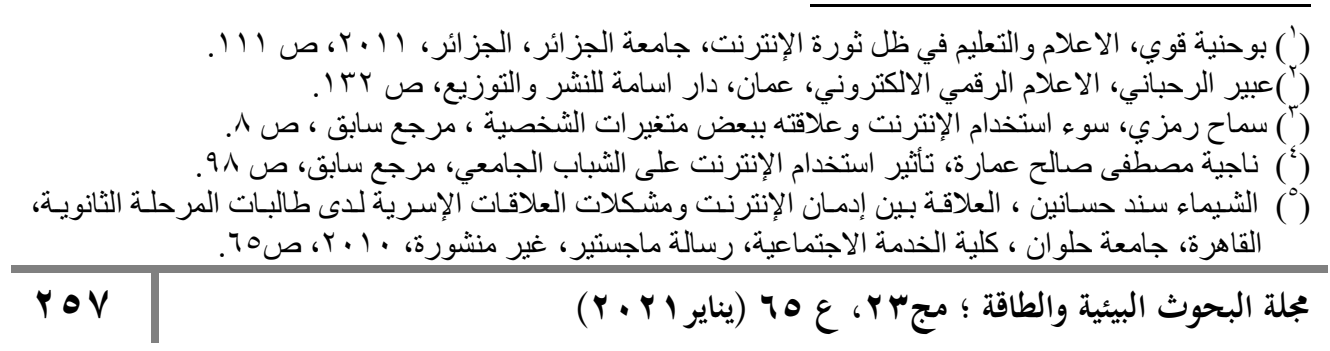


r- حاجات شخصية: ومن أمثلة الحاجات الشخصية التي تلبيها الإنترنت، فرص العمل والمواقع التي توجه المستخدم إلى كيفية الحفاظ على صحته.

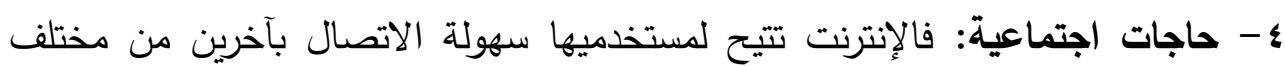

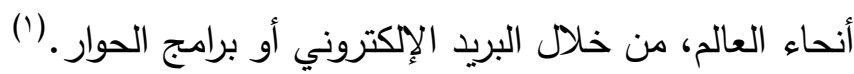

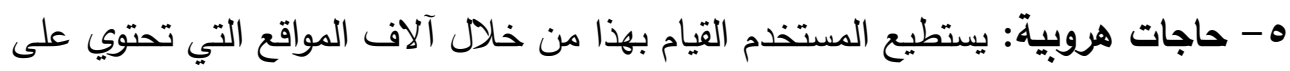
التسلية والترفيه والألعاب، التي يهرب فيها بمفرده أو مع غيره من الواقع إلى عالم

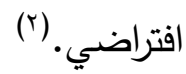

الآثار السلبية لسوء استخدام الإنترنت:

شبكة الإنترنت بما لها من قدرات فائقة تتجاوز حدود الزمان والمكان، من أهم

قضايا المجتمع في الوقت الحاضر ـ كيف لا، وهي تمثل وجه المجتمع المعلوماتي الجديد، بما تتشره من قيم وعادات وتقاليد وثقافة خاصة؛ فإذا كانت شبكة الإنترنت تتيح فرصاً كبيرة

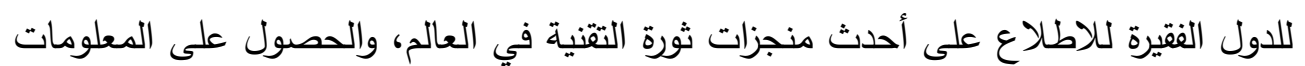
من مصادر عدة، فإن التعامل مع شبكة الإنترنت ينطوي على مخاطر وسلبيات هائلة

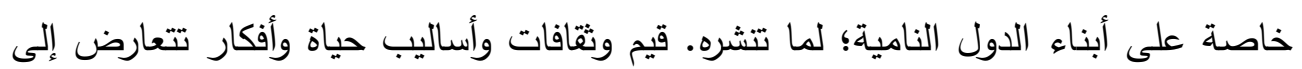
حد كبير مع ثقافتنا وقيمنا وتراثنا. (r) وفيما يأتي عرض لبعض سلبيات إساءة استخدام الإنترنت على المراهقين والشباب:

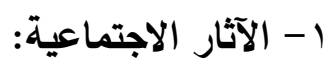

أ- العزلة الاجتماعية: يخشى كثير من الباحثين أن يؤدي الإنترنت إلى غياب التفاعل الاجتماعي؛ لأن التواصل فيها يحدث عبر أسلاك ووصلات لا بطريقة طبيعية، وهذا الاتصال غير الطبيعي يؤدي إلى تقلص العلاقات الاجتماعية، وعدم التكيف مع الآخرين،

$$
\begin{aligned}
& \text { (') سامية زكي يوسف احمد، شبكة الإنترنت وآثار ها على الثباب المصري دراسة سوسيولو جية، القاهرة، جامعة عين }
\end{aligned}
$$

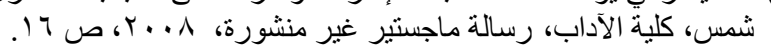

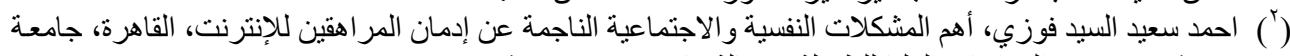

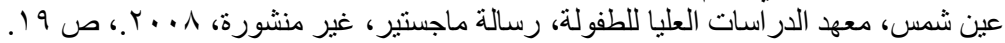

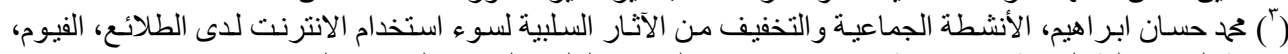

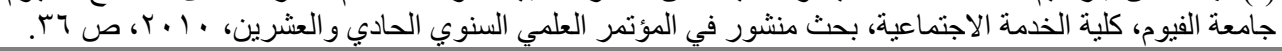

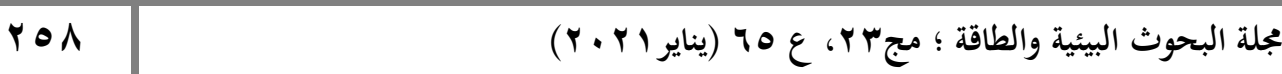


د/ فتحي جاب الله إدريس عبدالدايم

وعدم فتح مجالات للحوار، ومن ثم فمسيء استخدام الإنترنت لا يستطيع أن يتفاهم مع

ومستخدمو الإنترنت يسجلون انخفاضاً في معدلات التفاعل الأسري والدائرة

الاجتماعية المحيطة بهم؛ إذ يقضون وقتاً طويلاً في التقاعل مع شبكة الإنترنت والنتيجة الحتمية لذلك تكون تقلص الدائرة الاجتماعية للفرد والإصابة بالوحدة، والتعاسة، والبقاء دون أصدقاء، فالإفراط في استخدام هذه التقنية ينعكس على سلوك الإنسان وعلاقاته الاجتماعية، الذي يؤثر بشكل كبير على أسرته ومحيطه الاجتماعي. (؟) ب- التأثير على القيم الاجتماعية: ينشأ الثاب في كنف قيم اجتماعية خاصة تكون بيئة الجماعة الأولية، لكن ما يتعرض له في أثناء تجواله في شبكة الإنترنت من قيم له تأثثر

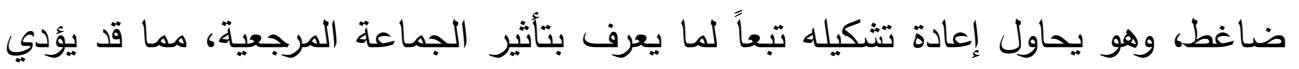
إلى محو آثار الجماعة الأولية عليه، ويفقده التواصل مع مجتمعه، ويعرضه للعزلة، ومن ثم

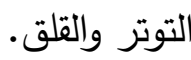

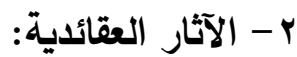

من مآسي الإنترنت، ما تزخر تلك الشبكة به من مواقع تروج للعقائد الباطلة

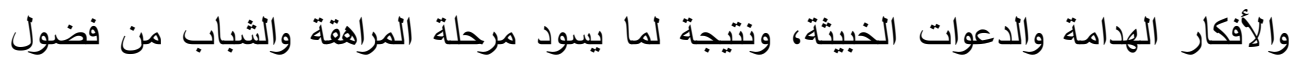
وعدم استقرار نفسي وفكري، وقع من الثباب العربي في حبائل جماعات مشبوهة، تعادي الوطن والدين وتهدد أمن المواطنين.(r) ب- الآثار الدراسية:

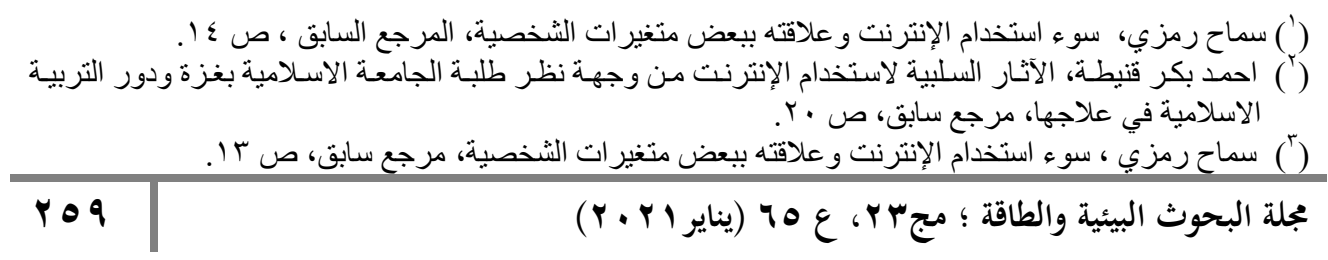


لسـوء اســتخدام الإنترنــت دور فـي تـدني مسـتويات بعـض الطـلاب الدراسـية؛

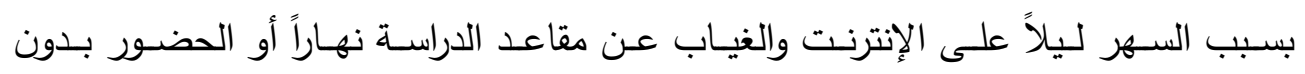
تركيز • وفيما يأتي بعض الآثار السلبية للإنترنت على مستوى الطلاب: لئل

سوء استخدام الانترنت قد يؤدي إلى انخفاض مستويات الطلاب وتكرر غيابهم عن لان لهن المحاضرات.

هثرة استخدام الإنترنت لا تترك للطلاب وقتاً للمذاكرة والدروس؛ لأن اغلب انتباههم وشعورهم يكون موجهاً إلى الإنترنت، ويؤدي هذا إلى مشكلات دراسية كثيرة.

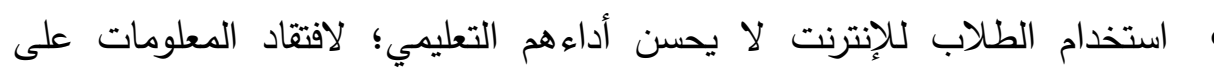
الإنترنت إلى النظام وعدم وجود علاقة مباشرة بين تلك المعلومات ومناهج الدراسة. الإفراط في استخدام الإنترنت يؤثر بالسلب على الابداع والذاكرة المطلوبة في النواحي الدراسية.

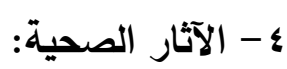

وفي مقدمتها اضطراب النوم وقلته بسبب الجلوس إلى الإنترنت لساعات طويلة، كذلك يؤثر طول مشاهدة شاشة الحاسوب أو الهاتف النقال على العيون بفعل طول تعرضها للأشعة المنبعثة من الجهاز، كذلك تسبب اضطراب الأكل، مع تتاولهم الطعام بسرعة بالإضافة إلى الإكثار من الوجبات السريعة المشبعة بالاهون، ثم إن هذا يقترن بقلة الحركة،

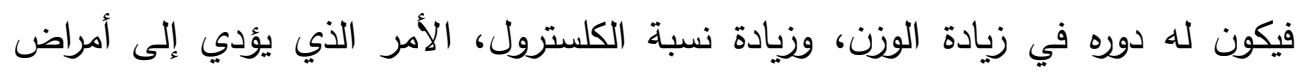

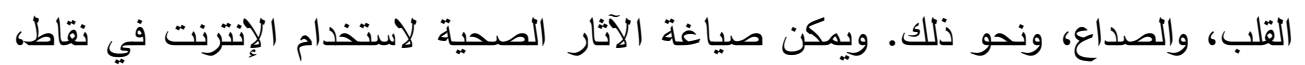
منها: 1 الإصابة باضطرابات النوم بصفة مستمرة، وحدوث تغيير دائم في أوقاته.

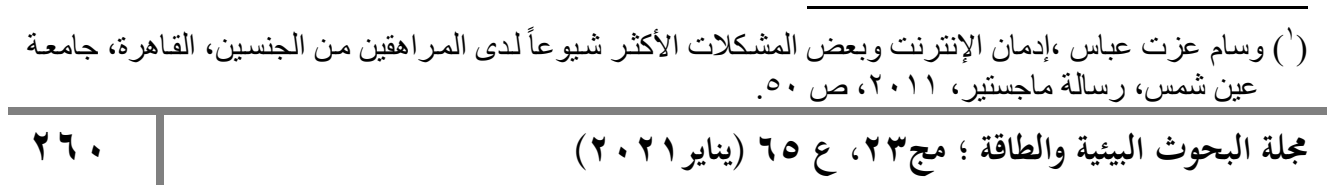


د/ فتحي جاب الله إدريس عبدالدايم

r- إرهاق العينين، وضعف البصر ، وتأثر عضلات العين بالإشعاع المبتعث عن شاشة الحاسوب. ب- آلام مستمرة بالظهر ؛ نتيجة الجلوس لساعات طويلة أمام الحاسوب دون حركة. ع- الإصابة بتشوهات العظام، خاصة عظام العمود الفقري وفقرات الرقبة، نتيجة الجلوس الخطأ. 0- التأثيرات السلبية على الجسم والمخ نتيجة الإشعاعات الكهرومغناطيسية الصادرة دن شاشة الحاسوب. ج- الإصابة بالتوتر الدائم، الذي يؤثر على الجهاز العصبي للفرد بالسلب. V- فقدان الثهية، مع العزلة عن الآخرين، والاستعاضة بالإنترنت عن ممارسة الأنشطة الرياضية والاجتماعية. 1- الثعور بالإرهاق الثديد الذي يؤثر على الأداء الطبيعي للفرد.

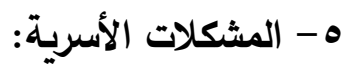

دور الأسرة مهم؛ إذ هي الخلية الأولى في بناء المجتمع الإنساني، والثكل الأساسي للبناء الاجتماعي، والمصدر الأصيل للتأثيرات الاجتماعية، والحضن الذي تتمو فيه بذور الشخصية، وتتكون اتجاهاتها، ويكتسب الأولاد منها المعايير والقيم والأنماط السلوكية المرغوبة التي تقود إلى الضبط الاجتماعي. إنها أول منظمة اجتماعية تباشر الضبط

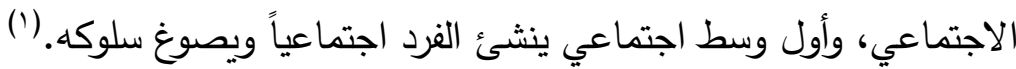

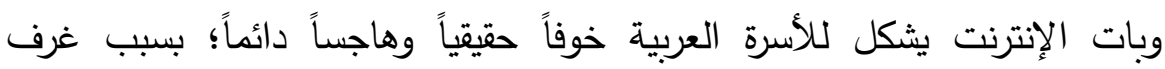
الدردشة التي يكون زوارها غالباً من المراهقين ، كما أن هناك مشكلات أسرية ناتجة عن إدمان الإنترنت تتلخص في إهمال الواجبات الأسرية مما يؤدي إلى حالة من الفوضى داخل

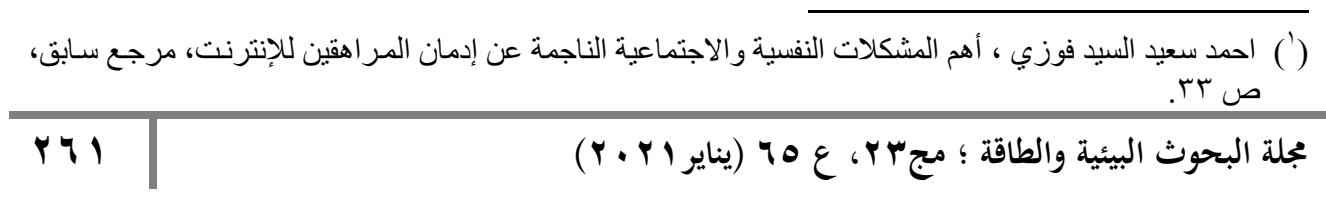


الأسرة وتتأثر العلاقات الزوجية بدرجة قد تصل إلى الطلاق، لا سيما إذا كانت للزوج

علاقات غرامية مع أخريات أو العكس. (') ومن ابرز آثار الإنترنت على الأسرة:

ا- الميل إلى العزلة، ومنها إلى قلة الانتماء الأسري، فيؤدي هذا إلى الىى الفراغ الاجتماعي والعاطفي. ץ- إهمال واجباته الأسرية والمنزلية، مما يؤدي إلى إثارة أفراد الأسرة عليه.

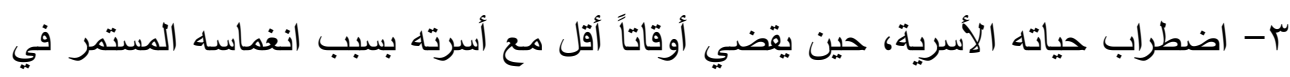
الإنترنت.

ع- الاصابة بالانطوائية نتيجة تفضيله الجلوس أمام الإنترنت على الخروج مع أقاربه

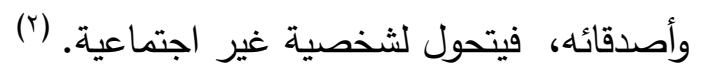

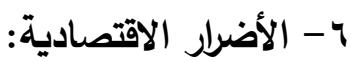
وتتمثل في الصرف على اشتراكات شركات الاتصالات أو في بعض المواقع التي تتطلب اشتراكات، وكذلك الصرف على أجهزة الحاسوب وملحقاتها. ويمكن تفصيل الأضرار الاقتصادية فيما يأتي: أ- الإنفاق على استعمال الشبكة: شبكة الإنترنت في العالم العربي من أعلى الشبكات في العالم من حيث التكلفة، مما يحمل الثاب أعباء وفواتير مالية قد تثقل كاهله وكاهل أسرته، الإنسا،

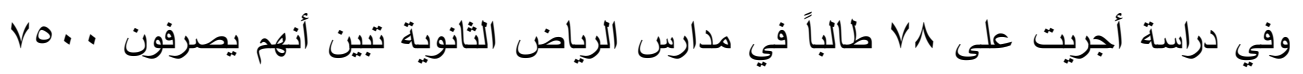
ريال أسبوعياً على مقاهي الإنترنت فقط، بخلاف ما يصرفونه على الاشتراكات المنزلية؛ ذلك أن 7 ؛ \% منهم لديهم اشتراكات منزلية. ب- تنمية سلوكيات استهلاكية سلبية: من سمات شبكة الإنترنت جاذبية العرض، وسهولة الشراء، مما يدفع المستهلكين - وخصوصاً الشباب - إلى شراء كماليات ربما لا يحتاجونها

(') احمد احمد بكر، الآثار السلبية لاستخدام الإنترنت من وجهـة نظر طلبة الجامعة الاسلامية بغزة ودور التربيـة

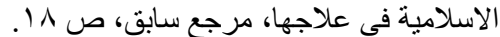

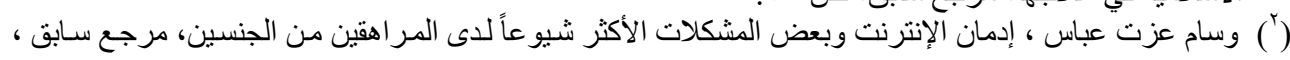


د/ فتحي جاب الله إدريس عبدالدايم

فعلاً، لينتقل التسوق من كونه وسيلة للحصول على الحاجيات إلى غاية بقصد التسلية وتمضية الوقت، مما يثقل كاهل الثاب وأسرته بالمصروفات، ويمنعه من توجيه موارده لبناء مستقبله. - الآثار الاجرامية للإنترنت : - الإن وقد يكون الثاب ضحية للجريمة، كما في جرائم النصب والاحتيال التي يكون ضحيتها المستخدم، ومنها ما تكون شبكة الإنترنت مسرحاً لتلك الجريمة. ومن المعلوم أن شبكة الإنترنت تحوي مواقع تدعو إلى الجرائم، وتشرح كيفية ارتكابها، حتى ساعدت على

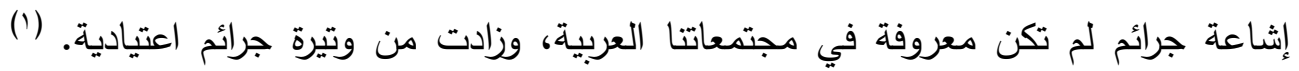
وجرائم الإنترنت من الجرائم المستحدثة، التي يقسمها الخبراء إلى نوعين أساسين، أولهما: الجرائم التي يكون الحاسب الآلي والإنترنت هدفاً لها، والثانية الجرائم التي يستخدمان فيها. ويمكن عرض بعض من جرائم الإنترنت كما يأتي: أ- صناعة الفيروسات ونشرها: وهي أوسع جرائم الإنترنت انتشاراً وتأثيراً. ب- الاختراقات: تتمثل في الاخول غير المصرح به إلى أجهزة أو شبكات، عن تأدية عملها دون أن تتم عملية اختراق فعلية لتلك الأجهزة. ج- المضايقة والملاحقة: تتم جرائم الملاحقة على شبكة الإنترنت غالباً باستخدام البريد الإلكتروني، أو وسائل الحوارات المختلفة على الثبكة. د- التشهير وتشويه السمعة: ينشر معلومات قد تكون سرية، أو مضللة، أو مغلوطة، وقد

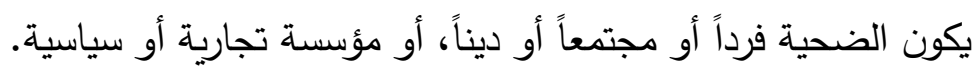
هـ - السرقة: قد تحدث السرقة باستخدام الحاسب على شبكة الإنترنت نتيجة اختراق نظام محلى، أو إقحام عملية مزورة من خلال الثبكة. والسرقة يمكن أن تكون لبعض المعلومات الحيوية المحظورة التي يمكن إفثاؤها أو بيعها أو قد تقع السرقة لأصول أخرى ذات قيمة أنها، مثل أرقام بطاقات الأتمان، التي يمكن أن تستغل لسحب مبالغ من رصيد صاحب البطاقة.

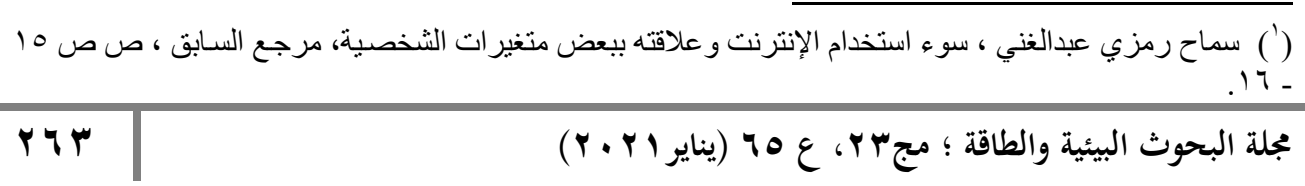


و - النصب والاحتيـال: غدت الإنترنت مجالاً رحباً لمن له سلع أو خدمات تجاريـة يريد أن

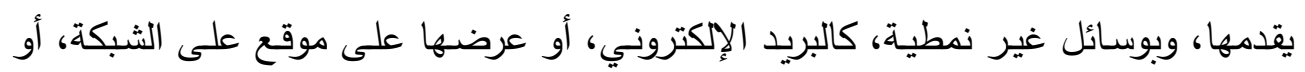

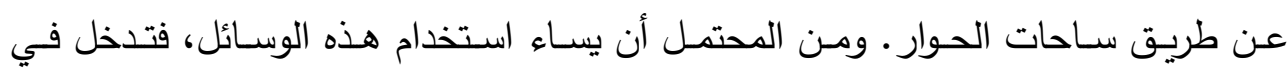
(') عمليات نصب واحتيال طرنق ساحات

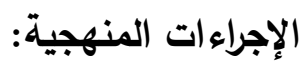

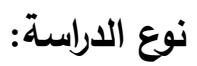

يسعى هذه البحث إلى وصف الآثار السلبية لاستخدام الإنترنت من قبل طلاب

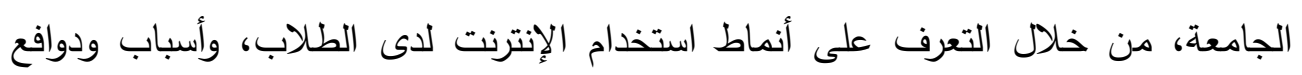

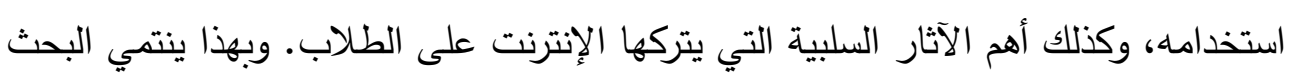
إلى البحوث الوصفية. منهج الدراسة: استخدم الباحث في دراسته هذه "المنهج الوصفي"، الذي راه المنهج المناسب الذي يخدم طبيعة هذه الدراسة وأغراضها ويفي بمتطلباتها البحثية. عينة الدراسة:

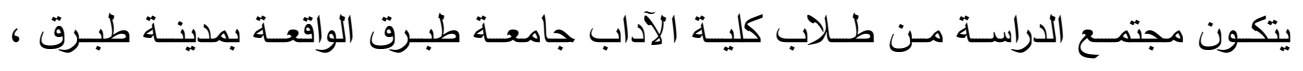

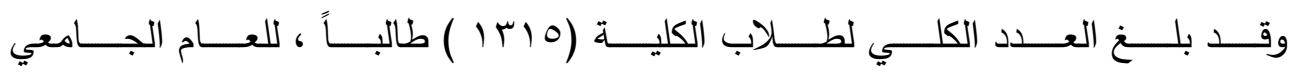

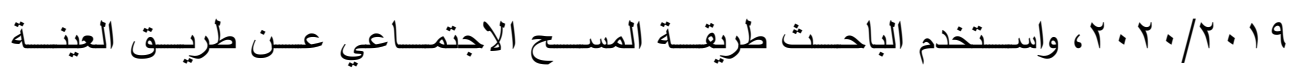

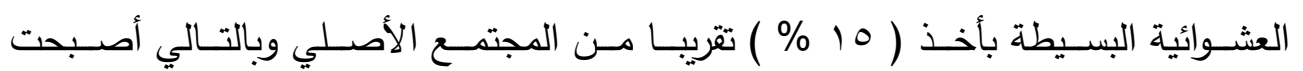

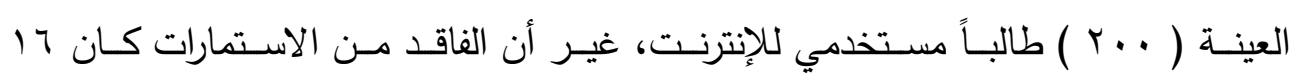

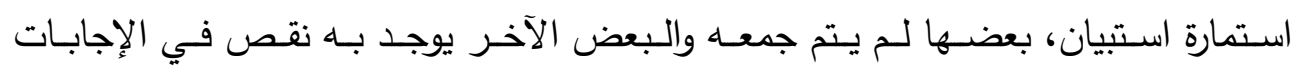

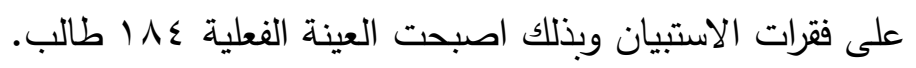

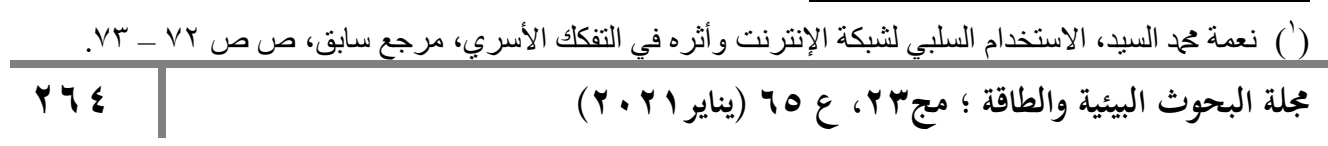


د/ فتحي جاب الله إدريس عبدالدايم

جدول رقم (1) يبين العينة حسب النوع

\begin{tabular}{|c|c|c|}
\hline \multicolumn{2}{|c|}{ الاراسة الأساسية } & \multirow[t]{2}{*}{ لوع الطالب } \\
\hline النسبة\% & العدد العد & \\
\hline \%०9.rrq & 1.9 & ذكور \\
\hline$\{\cdot . \vee 7 \uparrow$ & vo & إناث \\
\hline$\% 1 \ldots$ & $1 \wedge \varepsilon$ & المجموع \\
\hline
\end{tabular}

أداة الدراسة:

قام الباحث بإعداد وبناء استمارة استبان وذلك من خلال : الاطلاع على العديد من المراجع والأدبيات النظرية والدراسات السابقة ذات الصلة بالموضوع ، ثم قام بجمع الأفكار والأسئلة من المصادر السابقة، بالإضافة إلى مجموعة أخرى من الأسئلة وضعها الباحث، وتم تقسيم الاستمارة إلى عدة عناصر رئيسية تتضمن مجموعة من الأسئلة، وقد صيغت عناوين تلك العناصر في ضوء أهداف الدراسة، ثم قام الباحث بصياغة الأسئلة في شكلها النهائي، ومراجعتها، بالإضافة لمجموعة الأسئلة الخاصة بخصائص عينة الدراسة. صدق الأداة :للتحقق من صدق أداة الدراسة، قام الباحث بعرضها على مجموعة أسـاتذة للتأكد من السلامة العلمية للأداة من حيث :المضمون والصياغة اللغوية، ودرجة تحقيقها للغرض الذي صُممت من أجله، وتم تعديل بعض الفقرات التي اتفقت حولها آراء المحكمين. ثبات أداة الدراسة: للتحقق من ثبات الأداة، استخدمت طريقة الاختبار وإعادة الاختبار ، إذ وزع الباحث الأداة على 10 طالبا من خارج عينة الدراسة، وإعادة تطبيقها عليهم بعد مضي أسبوعين، وبعد ذلك جرى احتساب معامل الثبات باستخدام معامل ارتباط بيرسون، وبلغت

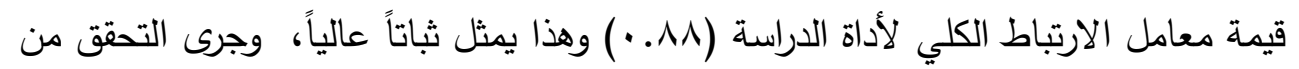
ثبات أداة الدراسة بطريقة الاتساق الداخلي، وذلك باستخدام معامل (كرونباخ الفا) لاختبار 
درجة توافق ردود المستجيبين على أسئلة الاستبانة، إذ تبين أن معاملات الثبات لهجالات الاستبانة جيدة ومقبولة لأغراض الدراسة، فقد بلغت قيم كرونباخ الفا للدرجة الكلية(؟ 9. • ).

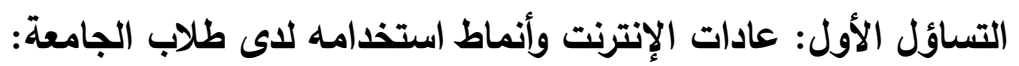

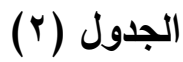

التكرار والنسبة المئوية والدلالات الإحصائية الخاصة بمدة استخدام الإنترنت لعينة البحث

$1 \Lambda \varepsilon=ن$

\begin{tabular}{|c|c|c|c|}
\hline \multicolumn{2}{|c|}{ الدلالات الإحصائية } & \multirow{2}{*}{ التصنيف } & \multirow{2}{*}{ المتغير } \\
\hline النسبة\%\% & الت التكرار & & \\
\hline$\% \wedge .10 r$ & 10 & أقل من سنة & \multirow{5}{*}{ تستذ متى } \\
\hline$\%) 7 . \wedge \leqslant \vee$ & r & من سنة - أقل من سنتين & \\
\hline$\% \circ r . I V \leq$ & 97 & من سنتين أقل من ساسنوات & \\
\hline \%rY.Arт & $\varepsilon r$ & ثلاث سنوات فأكثر & \\
\hline$\% 1 \ldots$ & $1 \wedge \varepsilon$ & المجموع & \\
\hline
\end{tabular}

يتضح من الجدول أن غالبية عينة البحث تستخدم الإنترنت لمدة تتراوح من سنتين

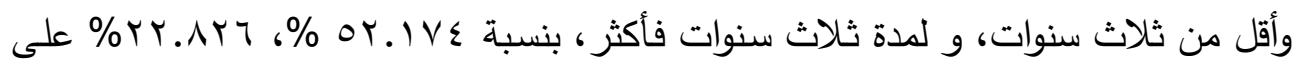
الترتيب، بينما الفئات الأقل استخداماً للإنترنت هم من يستخدمونه لمدة من سنة إلى أقل من

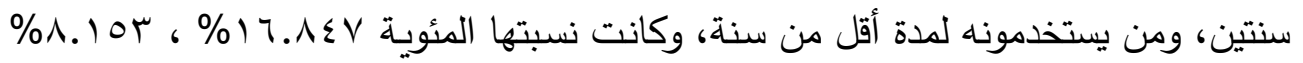
على التوالي. ويلاحظ أن أفراد عينة البحث شرعوا في استخدام الإنترنت متأخرين، ، وربما كان ذلك راجعاً إلى صغر سنهم قبل الجامعة، كما أن كثيراً من التسهيلات الموجودة في الإنترني أثناء فترة الدراسـة للحصـول على خط الإنترنت لـ تكن موجودة مـن قبل، كمـا أن ارتفاع تكاليف الاشتراك في شبكة الإنترنت قد تدفع أولياء الأمور إلى عدم السماح لأبنائهم قبل هذه

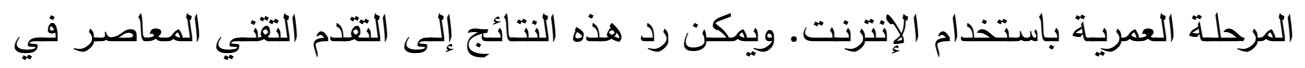
الانترنت، في الفترة من سـنتين وأقل من ثـلاث سنوات؛ ولعل مـن أسباب زيـادة استخدام 
د/ فتحي جاب الله إدريس عبدالدايم

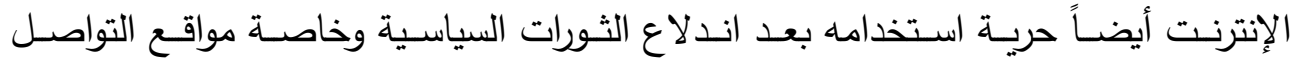

الاجتماعي. ولعل أكثرها شيوعاً الفيس بوك وتويتر واليوتيوب.

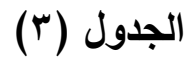

التكرار وإلنسب المئوية والدالات الإحصائية لأماكن استخدام الانترنت، لعينة البحث ن =

$1 \wedge \varepsilon$

\begin{tabular}{|c|c|c|c|}
\hline \multicolumn{2}{|c|}{ الدلالات الإحصائية } & \multirow{2}{*}{ التصنيف } & \multirow{2}{*}{ المتغير } \\
\hline النسبة\%\% & التكرار & & \\
\hline$\% \vee \neg . . \wedge \vee$ & $1 \leqslant$. & في المنزل & \multirow{4}{*}{ مكان } \\
\hline$\% \backslash \wedge . \leqslant \vee q$ & $r \varepsilon$ & في الجامعة & \\
\hline$\% 0 . \varepsilon r \varepsilon$ & 1. & عند أصدقائي & \\
\hline$\% 1 \ldots$ & $1 \wedge \varepsilon$ & المجموع & \\
\hline
\end{tabular}

ويتضح من الجدول رقم (r) أن معظم عينة البحث تستخدم الإنترنت في المنزل، ،

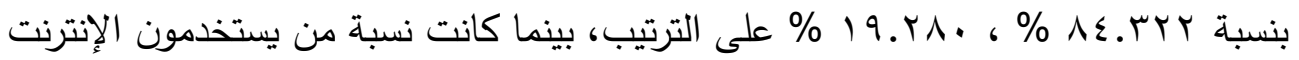
في الجامعة وعند أصدقائهم أقل، حيث بلغت نسبهم الترتيب.

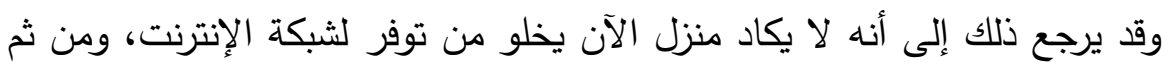

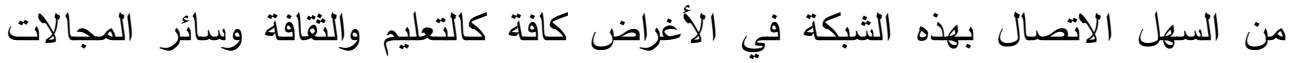

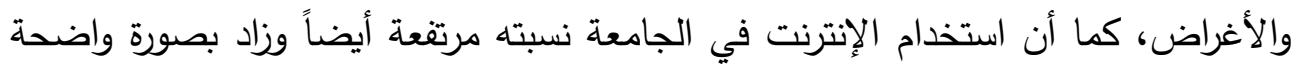

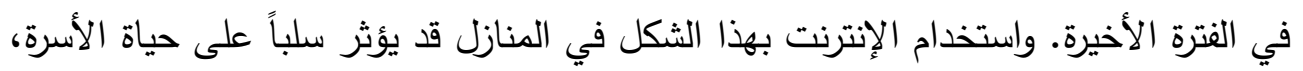

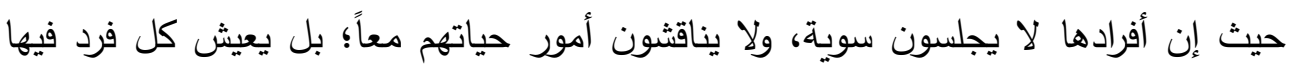
حياته بشكل افتراضي على الإنترنت.

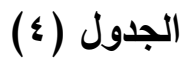


الآثار السلبية لاستخدام الإنترنت على طلاب الجامعة

التكرار والنسب المئوية والدلالات الإحصائية لإجابات سؤال مع من تستخدم الانترنت

لعينة البحث ن = الإله

\begin{tabular}{|c|c|c|c|}
\hline \multicolumn{2}{|c|}{ الالالات الإحصائية } & \multirow{2}{*}{ التصنيف } & \multirow{2}{*}{ المتغير } \\
\hline النسبة\%\% & التكرار & & \\
\hline$\% \vee \vee . \vee \backslash \wedge$ & $1 \leqslant r$ & بمغردي & \multirow{5}{*}{ مـع من تستخدم } \\
\hline$\% \wedge .797$ & 17 & مع أسرتي & \\
\hline$\% \vee . .70$ & 14 & مع أقاربي & \\
\hline$\% 7.041$ & ir & مع الأصدقاء & \\
\hline$\% 1 \ldots$ & $1 \wedge \varepsilon$ & المجموع & \\
\hline
\end{tabular}

ويتضح من الجدول رقم (ع)أن العدد الأكبر من أفراد عينة البحث يستخدمون

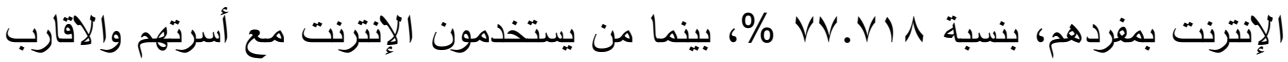

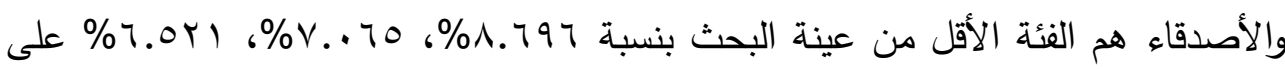
الترتيب.

وقـد ترجـع هذه النتائج إلى أنـهـ مـع وجـود أجهزة ذكيـة في معظم المنـازل، ومـع ظهور مواقـع التواصـل المختلفـة كـالفيس بـوك والـواتس آب واليوتيـوب والفــيير ، وغيرهـا التـي

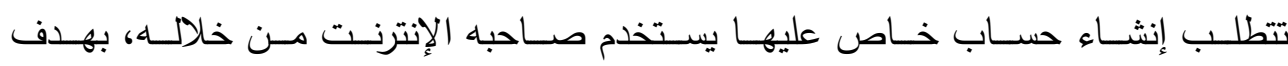

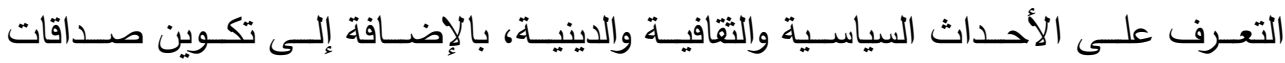

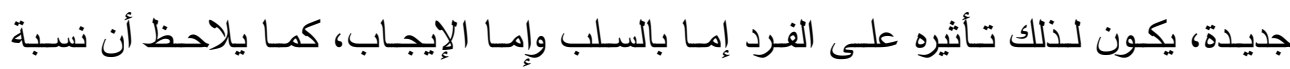

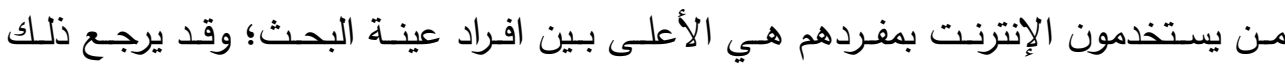

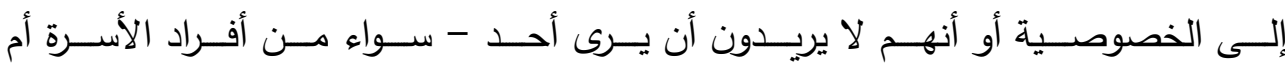

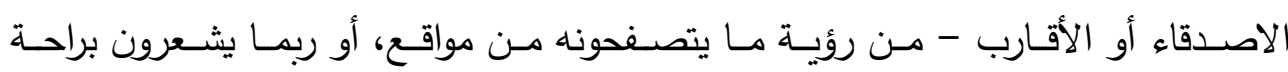
أكثر وهم يستخدمون الإنترنت بعيداً عن عيون الآخرين.

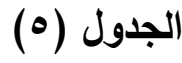

Y

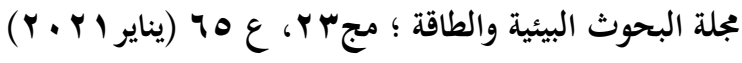


د/ فتحي جاب الله إدريس عبدالدايم

التكرار والنسب المئوية والدلالات الإحصائية بمدة استخدام الانترنت يوميا لعينة البحث ن

$11 \leq=$

\begin{tabular}{|c|c|c|c|}
\hline \multicolumn{2}{|c|}{ الالالات الإحصائية } & \multirow{2}{*}{ التصنيف } & \multirow{2}{*}{ المتغير } \\
\hline النسبة\%\% & التكرار & & \\
\hline$\% \wedge .10 r$ & 10 & أقل من ساعة & \multirow{5}{*}{ مدة استخدام } \\
\hline \%rr.Art & $\varepsilon r$ & من ساعة الى أقل من & \\
\hline$\%$ \%.าจ & 119 & ساعات ساعتين إلى ثلاث & \\
\hline$\% \varepsilon . r \leq V$ & $\wedge$ & اكثر من ثلاث ساعات & \\
\hline$\% 1 \ldots$ & $1 \wedge \varepsilon$ & المجموع & \\
\hline
\end{tabular}

يتضـــ مـن الجدول السـابق أن معظم أفراد عينـة البحث يستخدمون الإنترنـت مـن

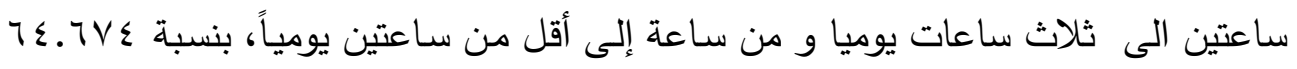

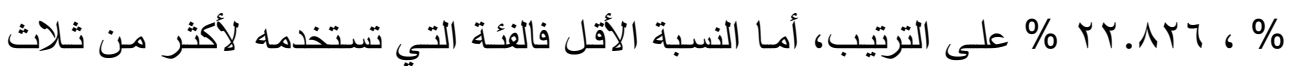

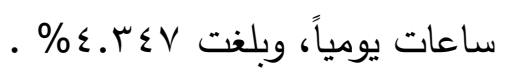

واستخدام الشباب للإنترنت لأكثر من ساعتين يومياً يوحي بأنهم لا يعيرون للوقت

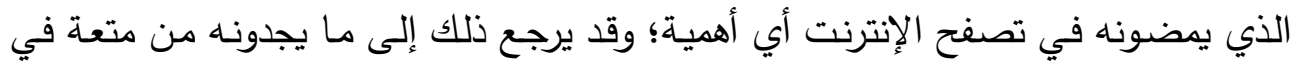
التحاور مع الأصدقاء أو الأقارب. وينتج عن ذلك إهمال الواجبات المنوطة بهم، سواء أكانت

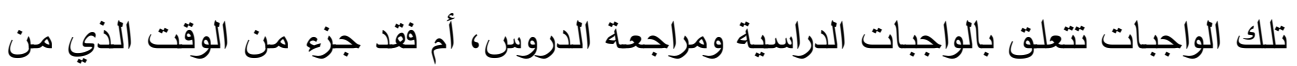
المفترض أن يقضيه بين أفراد أسرته.

جدول (7)

التكرار والنسب المئوية لمواقع التواصل الاجتماعي التي تستخدمها عينة البحث ن =

IN

\begin{tabular}{|c|c|c|c|}
\hline الترتيب & الدلالات الإحصائية & التصنيف & المتغير \\
\hline
\end{tabular}

หq9

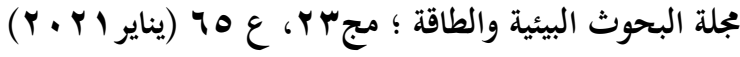


الآثار السلبية لاستخدام الإنترنت على طلاب الجامعة

\begin{tabular}{|c|c|c|c|c|}
\hline & النسبة\%\% & التكرار & & \\
\hline 1 & $\% \wedge \varepsilon . r r q$ & 100 & الفيس بوك & \\
\hline r & $\%$ \% & 111 & واتس آب & \\
\hline 0 & $\% \Gamma \cdot . \leqslant r \varepsilon$ & 07 & فايير & مواقع \\
\hline r & \%०q.rrq & 1.9 & ماسينجر & التواصل \\
\hline 7 & $\% \vee . .70$ & $M$ & تويتر & الاجتماعي \\
\hline$\varepsilon$ & $\% \leqslant \Lambda . r \vee$. & 19 & يوتيوب & التي \\
\hline V & $\% 0.9 \vee \wedge$ & 11 & إنستجرام & تستخدمها \\
\hline
\end{tabular}

تحتوي شبكة الإنترنت على عدد كبير من المواقع والتي يمكن تصنيفها بطرق مختلفة؛ فهناك المواقع المفيدة والضارة، وثالثة تحتمل الاحتمالين واستخدام الفرد لها هو ما لإلير

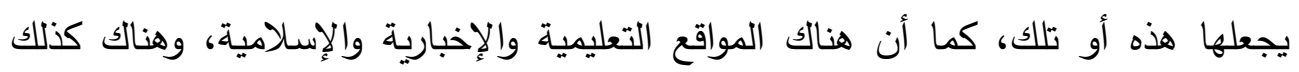

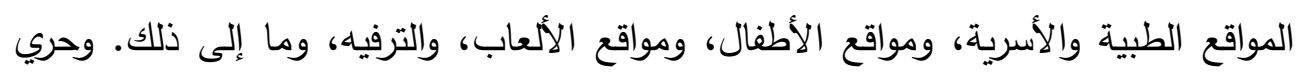

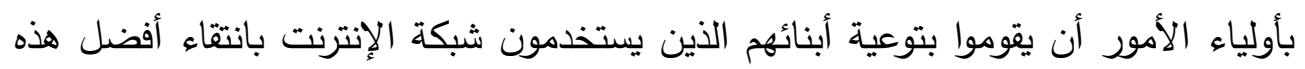

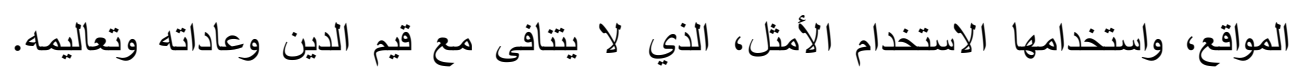

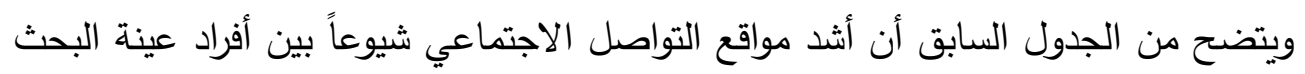

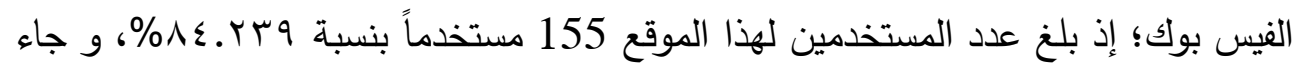

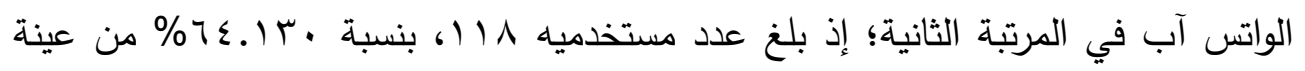

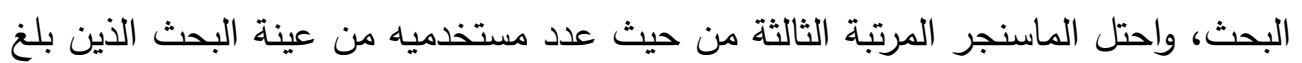

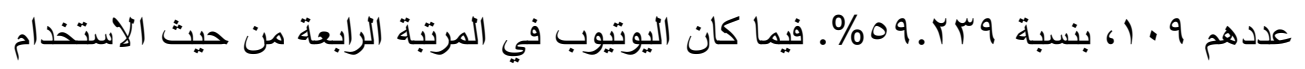

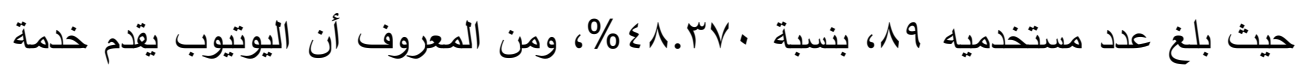
عرض مقاطع الفيديو. والسؤال الذي يطرح نفسه هنا: كيف يكون استخدام هؤلاء الطلاب

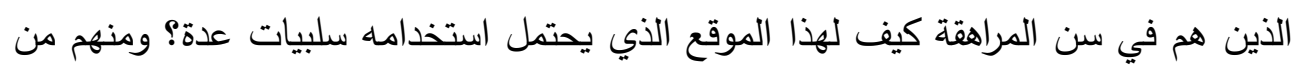
يشاهد المقاطع الاباحية التي عادة ما تغري الثباب في مثل هذه السن، وقد يكون الدافع إلى rV.

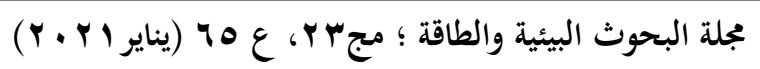


د/ فتحي جاب الله إدريس عبدالدايم

هذه النقائص الرغبة في خوض مغامرة جديدة لإشباع بعض الرغبات الملحة. ويلي هذه المواقع في كثرة الاستخدام من قبل أفراد عينة البحث الفايبر؛ إذ بلغ عدد مستخدمي هذا لإنا

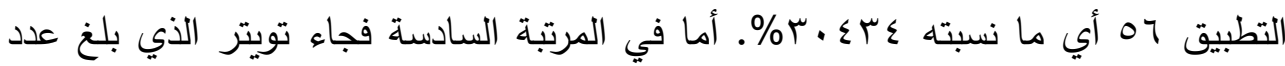

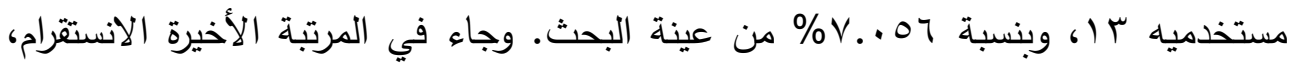

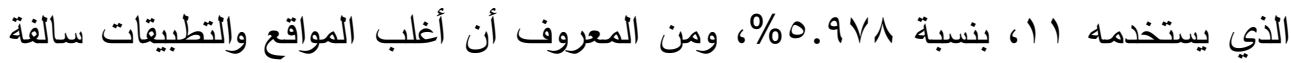
الذكر تستخدم في الدردشة، سواء أكان ذلك بشكل فردي بين صديق و آخر أم بالدخول في غرف الدردشة الجماعية، ولعل تلك الدردشة أكثر ما يسلب الطلاب أوقاتهم، ويشغلهم عن كثير من الواجبات، أو يعزل الفرد عن سائر أفراد أسرته. كما أن أساءة استعمالها يسبب الباب كثيراً من المشكلات، لأنه يستخدم صوتاً وصورة حيين للطرفين، وقد يقع الكبار البالغين في مشكلات جراء استخدامه فما بالك بشباب مقبلين على الحياة بشغف. (v) الجدول

التكرار والنسب المئوية والدلالات الإحصائية الخاصة بأوقات استخدام الانترنت لعينة البحث ن الإن

\begin{tabular}{|c|c|c|c|c|}
\hline \multirow{2}{*}{ الترتيب } & \multicolumn{2}{|c|}{ الدلالات الإحصائية } & \multirow{2}{*}{ التصنيف } & \multirow{2}{*}{ المتغير } \\
\hline & النسبة\%\% & التكرار & & \\
\hline r & $\% \backslash 7 . r)$ & r. & للجامعة صباحا قبل الذهاب & \multirow{4}{*}{ أوقات الإنترنت } \\
\hline$\varepsilon$ & $\% 1 . .110$ & 19 & في أثناء تواجدي بالجامعة & \\
\hline 1 & $\% \wedge \wedge . . \leq r$ & $17 r$ & مساءً & \\
\hline r & $\% \backslash$ Y.० & rr & في وقت متأخر من الليل & \\
\hline
\end{tabular}

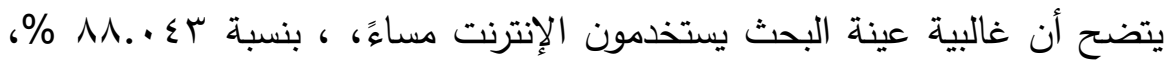
وقد ترجع هذه النتائج إلى أن الطالب يجد أكثر الأوقات المناسبة لاستخدام الإنترنت هي فترة المساء، كما أن هذا الوقت وقت فراغ الطلاب بعد انقضاء اليوم الدراسي؛ فهو ملائم للإبحار في الإنترنت، للتعليم، أو التواصل الاجتماعي مع الأقارب والأصدقاء. 
الآثار السلبية لاستخدام الإنترنت على طلاب الجامعة

التساؤل الثاني: دوافع الطلاب لاستخدام الإنترنت:

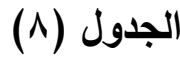

التكرار والنسب المئوية الخاصة (بدوافع التسلية والترفيه لاستخدام الإنترنت) لعينة البحث

$1 \wedge \varepsilon=\dot{0}$

\begin{tabular}{|c|c|c|c|c|}
\hline \multirow{2}{*}{ الترتيب } & \multicolumn{2}{|c|}{ الدلالات الإحصائية } & \multirow{2}{*}{ التصنيف } & \multirow{2}{*}{ المتغير } \\
\hline & النسبة\%\% & التكرار & & \\
\hline 1 & \%тr.oNV & $11 \mathrm{~V}$ & قضاء وقت الفراغ & \multirow{4}{*}{ والتسلية } \\
\hline r & $\% 01.790$ & $1 \cdot 1$ & اللعب بالألعاب & \\
\hline$\varepsilon$ & $\% \vee .7 . \wedge$ & $1 \leq$ & حل بعض الألغاز & \\
\hline r & $\%$ \% .VA & $7 \varepsilon$ & الاستماع للأغاني & \\
\hline
\end{tabular}

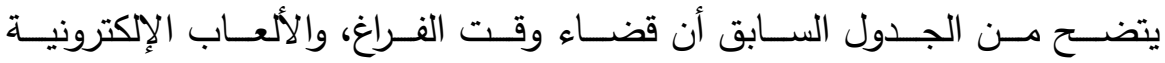

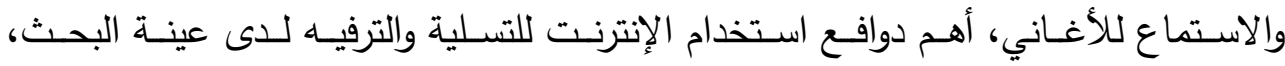

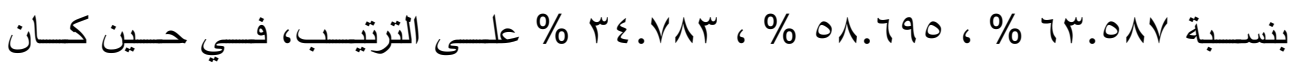

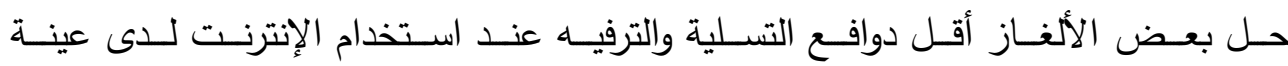
البحث بأقل نسبة، وهي تلك التي بلغت 1 . . . \% \% . وقد ترجع هذه النتائج إلى طول أوقات الفراغ، التي يحتاج الطلاب إلى أن يشغلوها

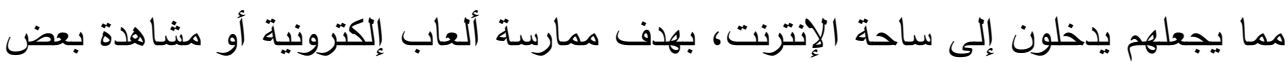
الأفلام أو الأعمال الدرامية أو التواصل الاجتماعي أو التعرف على الأحداث السياسية والرياضية والاقتصادية. وتوصلت بعض الأبحاث العلمية إلى أنه على الرغم من الفوائد التي

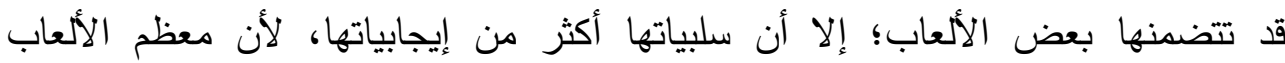
المستخدمة ذات مضامين سلبية، ولها آثار سلبية جداً عليهم، وتتمثل في الآثار الصحية التي قد تصيب مستخدميه، حيث حذر خبراء الصحة من تعود الشباب على استخدام أجهزة 
د/ فتحي جاب الله إدريس عبدالدايم

الكمبيوتر والإدمان عليها في الدراسة واللعب ربما يعرضهم إلى مخاطر وإصابات قد تتتهي إلى إعاقات أبرزها إصابات الرقبة والظهر •

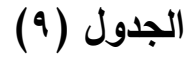

التكرار والنسب المئوية الخاصة (بدوافع التعليمية والثقافية لاستخدام الإنترنت) لعينة

البحث ن ع 1 الت

\begin{tabular}{|c|c|c|c|c|}
\hline \multirow{2}{*}{ الترتيب } & \multicolumn{2}{|c|}{ الدلالات الإحصائية } & \multirow{2}{*}{ التصنيف } & \multirow{2}{*}{ المتغير } \\
\hline & النسبة\%\% & التكرار & & \\
\hline r & $\% \leq 9 . \leq 07$ & 91 & زماجعة المحاضرات مع & \multirow{5}{*}{ الالإلتعافع الإنقية } \\
\hline$\varepsilon$ & $\% r \cdot . \leq r \leq$ & 07 & تحميل المحاضرات & \\
\hline 0 & $\% 7.0 Y 1$ & Ir & للتواصل مع أساتذتي & \\
\hline r & $\% 7 v . r q 1$ & IY & لزيادة ثقافتي & \\
\hline 1 & $\% \wedge \varepsilon . \vee \wedge r$ & 107 & في المتابعة الأحداث اليومية & \\
\hline
\end{tabular}

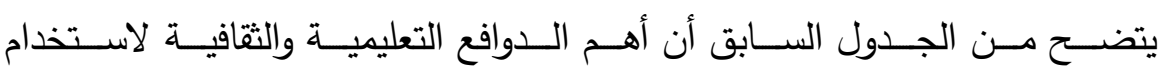

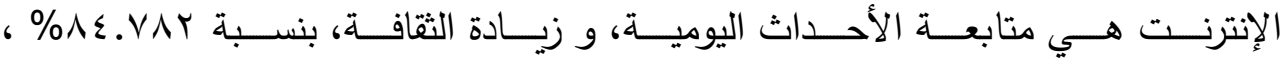

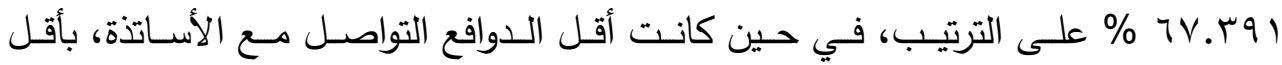

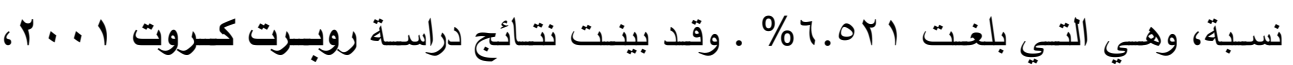

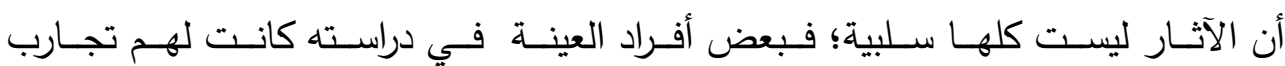
إيجابية ناجحة وايجابية مع الإنترنت كالإفادة منه في التعليم. وهذه النتائج تعطينا مؤشراً في كون وسائل الإعلام تقوم بدور حيوي في نشر ثقافة

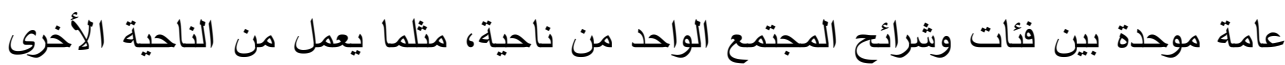
على التقريب بين الثقافات المختلفة، ويساعد بالتالي على نشر روح الاحترام من خلال

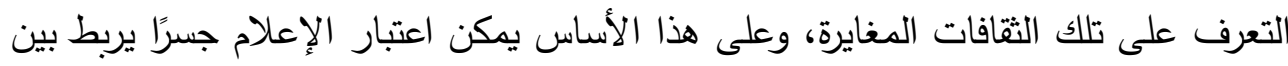


حياة الأفراد الثخصية الخاصة، والعالم الكبير الذين يعيشون فيه؛ بحيث يستطيع الفرد أن يَرى نفسه من خلال البرامج التي تبثها وسائل الإعلام المختلفة. الجدول (1.)

التكرار والنسب المئوية والدلالات الإحصائية الخاصة (بالدوافع الاجتماعية لاستخدام

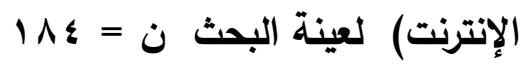

\begin{tabular}{|c|c|c|c|c|}
\hline \multirow{2}{*}{ الترتيب } & \multicolumn{2}{|c|}{ الدلالات الإحصائية } & \multirow{2}{*}{ التصنيف } & \multirow{2}{*}{ المتغير } \\
\hline & النسبة\%\% & التكرار & & \\
\hline r & $\% \backslash r . . \leqslant r$ & $r \varepsilon$ & إثبات ذاتي & \multirow{4}{*}{ الاجتماعية الاوافع } \\
\hline$\varepsilon$ & $\% \wedge .790$ & 17 & اكتساب مكانة اجتماعية & \\
\hline 1 & $\% q \leq \ldots . r)$ & IVT & للتواصل مع الأصدقاء & \\
\hline r & $\% \leq \vee . \wedge Y \uparrow$ & $\wedge \wedge$ & التعرف على أصدقاء جدد & \\
\hline
\end{tabular}

يتضح من الجدول السابق أن التواصل مع الأصدقاء والأقارب البعيدين، و التعرف على أصدقاء جدد، وإثبات الذات، أهم الدوافع الاجتماعية لاستخدام الإنترنت لاى له عينة

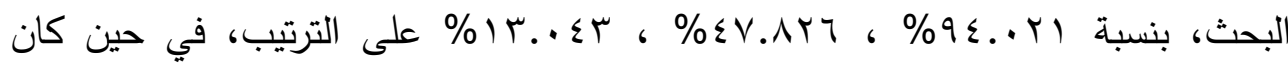
اكتساب مكانة اجتماعية أقل الدوافع الاجتماعية لاستخدام الإنترنت لدى عينة البحث بأقل نسبة؛ إذ بلغت 790.19\%. وترجع هذه النتائج إلى أن مواقع التواصل الاجتماعي المختلفة

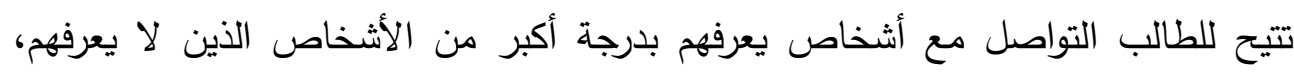
وبالتالي يكون التواصل مع الأصدقاء والأقارب البعيدين، والتعرف على أصدقاء جدد، وإثبات الذات أهم الدوافع الاجتماعية لاستخدام الإنترنت.

\section{الجدول (11)}

التكرار والنسب المئوية والدلالات الإحصائية الخاصة (بالدوافع السياسية لاستخدام

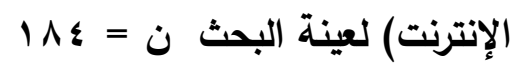


د/ فتحي جاب الله إدريس عبدالدايم

\begin{tabular}{|c|c|c|c|c|}
\hline \multirow{2}{*}{ الترتيب } & \multicolumn{2}{|c|}{ الدلالات الإحصائية } & \multirow{2}{*}{ التصنيف } & \multirow{2}{*}{ المتغير } \\
\hline & النسبة\%\% & التكرار & & \\
\hline r & $\% \circ \vee .7 .1$ & 1.7 & تتمية ثقافتي السياسية & الدوافع \\
\hline 1 & \%Vr.rฯq & o & التعبير عن رأيي بحرية & السياسية \\
\hline r & $\% \leqslant V . Y \wedge T$ & $\wedge \vee$ & مناقشة القضايا السياسية & الإسترنت \\
\hline
\end{tabular}

ويتضح من الجدول السابق أن أهم الدوافع السياسية لاستخدام الإنترنت، التعبير

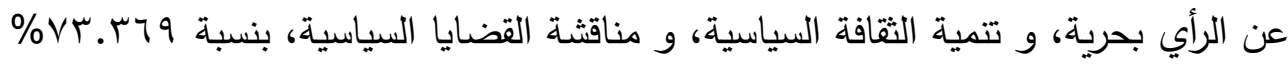

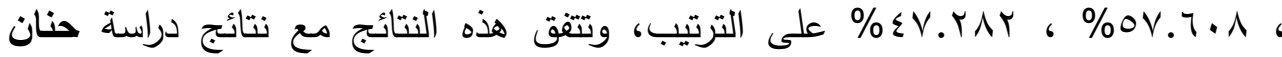

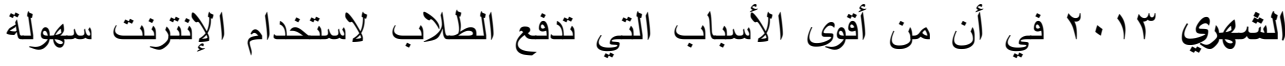
التعبير عن آرائهم واتجاهاتهم الفكرية التي لا يستطيعون التعبير عنها في عالمهم الحقيقي. وقد ترجع هذه النتائج إلى التغيرات السياسية التي شهدتها الساحة العربية فى الفترة الأخيرة، والثورات السياسية، التي ارتبطت بظهور مواقع التواصل الاجتماعي، كالثيس بوك الذى يدخل الطالب إليه بهدف التعبير عن الآراء أو متابعه الأخبار والقضايا الإقليمية، إضافة إلى متابعة الأحداث السياسية المختلفة. وبواسطة الانترنت، وشبكات التواصل الاجتماعي والهواتف الخلوية والتكنولوجيات الأخرى المرتبطة بالمعلومات والاتصالات، أصبح للناس وسائل كثيرة لبحث المعلومات واستقبالها ونقلها في جميع أنحاء العالم، وأثرت هذه الأمور على حياة الناس وتعدت ذلك ليصل التغيير حتى في أنظمة الحكم. التساؤل الثالث: الآثار السلبية لاستخدام الإنترنت:

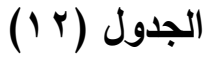

التكرار والنسب المئوية وإلدلالات الإحصائية الخاصة (بآثار الإنترنت على الجوانب

التعليمية) لعينة البحث ن = 184

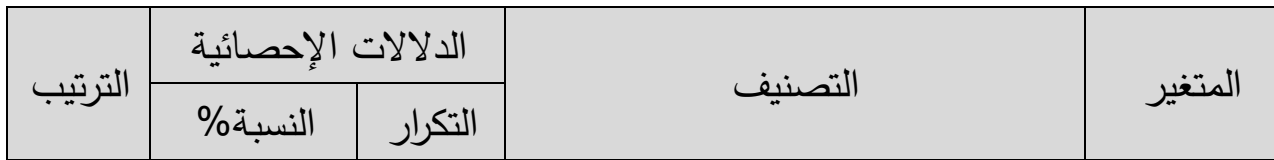

rVo

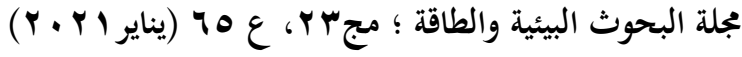


الآثار السلبية لاستخدام الإنترنت على طلاب الجامعة

\begin{tabular}{|c|c|c|c|c|}
\hline V & $\% \wedge .10 r$ & 10 & 1- الغياب عن الجامعة. & \multirow{7}{*}{ لإنترن } \\
\hline 1 & $\% \vee \leqslant . \leqslant 07$ & ITV & المحاضرات. - ضياع وقت مراجعة & \\
\hline 7 & $\% r \cdot . \leqslant r \leqslant$ & 07 & r- أتغيب عن بعض المحاضرات. & \\
\hline$\varepsilon$ & $\% \leq \wedge .91 \%$ & 9. & ع- ـ السهر على الإنترنت يشعرني & \\
\hline r & $\% 79.070$ & IrA & مشاركتي أثناء المحاضرة. & \\
\hline r & $\% 0 \leq . \wedge 91$ & 1.1 & צ- تراجع مستواي الدراسي. & \\
\hline 0 & $\% \leq 1 . \wedge \leq \vee$ & VV & إلي الرسوب. - استخدام الإنترنت بكثرة يؤدي & \\
\hline
\end{tabular}

ويتضح من الجدول السابق أن أشهر الآثار السلبية للإنترنت على الجوانب التعليمية، ضياع وقت مراجعة الدروس، وقلة المشاركة في المحاضرات، وتراجع المستوي

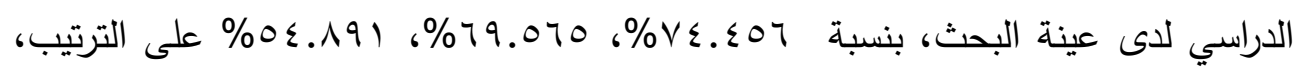
في حين كانت أقل الآثار السلبية للإنترنت على الجوانب التعليمية لإى عينة البحث، الغياب

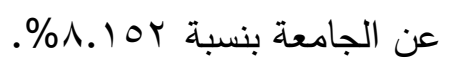

ومن هذه النتائج يتضح إن سوء استخدام الإنترنت يؤدى إلى هذه المشكلات

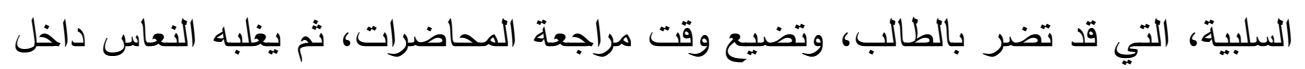
المحاضرة، نتيجة قضاء وقت طويل في السهر مع الإنترنت. ثم العزوف عن المشاركة في لي المحاضرات. بمعنى إن وجود وسائل التواصل الاجتماعي وخاصة الأجهزة الأكية مع الإسع

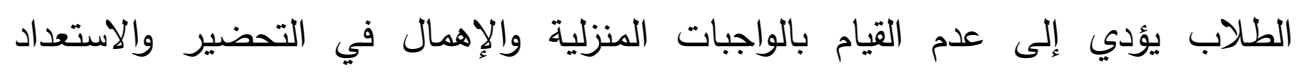
للامتحانات، وإن الانشغال في التواصل مع الأصدقاء والجروبات يؤدي إلى عدم الاكتراث

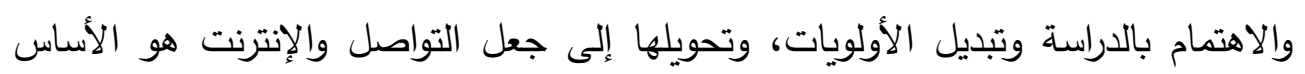
والدراسة والتحصيل العلمي مرحلة ثانوية. 
د/ فتحي جاب الله إدريس عبدالدايم

\section{الجدول (T I I)}

التكرار والنسب المئوية والدلالات الإحصائية الخاصة (بآثار الإنترنت على العلاقات

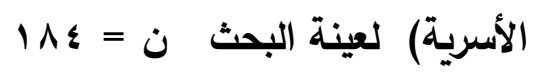

\begin{tabular}{|c|c|c|c|c|}
\hline \multirow{2}{*}{ الترتيب } & \multicolumn{2}{|c|}{ الدلالات الإحصائية } & \multirow{2}{*}{ التصنيف } & \multirow{2}{*}{ المتغير } \\
\hline & النسبة\% & التكرار & & \\
\hline r & $\% \vee r . r \wedge r$ & rזו & 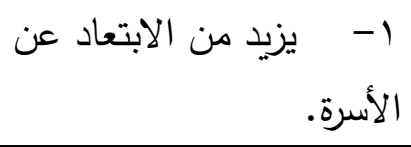 & آثار \\
\hline 0 & $\% \backslash 1 . \Sigma 1 T$ & r) & 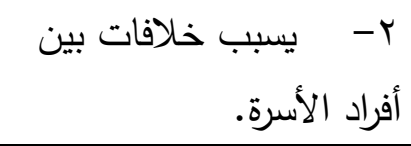 & الإنترنت \\
\hline 1 & $\% \vee 9 . \wedge 91$ & $1 \leqslant V$ & أقضيه مع أسرتي. & الألعلاقات \\
\hline r & \%оr.r. & 91 & ع عالدي. قلل من علاقاتي & \\
\hline$\varepsilon$ & rv.o & 79 & بإخوتي. & \\
\hline
\end{tabular}

ويتضح من الجدول السابق أن قلة الوقت الذى يقضيه الطالب مع الأسرة، وزيادة الابتعاد عن الأسرة أكثر الآثار السلبية للإنترنت على العلاقات الأسرية لاى عينة البحث، لونه

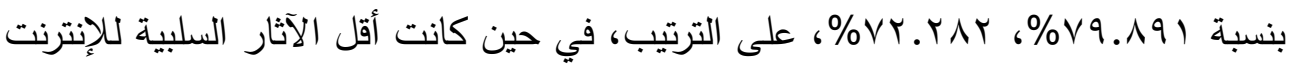
على العلاقات الأسرية لاى عينة البحث، يسبب خلافات بين أفراد الأسرة بأقل نسبة و بلغت . \% 1.

وقد ترجع هذه النتائج إلى طول الفترة التي يقضيها الطالب مع الإنترنت وتسبب ابتعاده عن أسرته وتجنبه الزيارات العائلية، وهذا راجع إلى التحولات التقنية التي أفرزت تفاعلات جديدة للعلاقات الأسرية وأدت إلى تعزيز العزلة والتتافر بين أفرادها وتلاشى قيم إنى التواصل الأسري، واستبدل الأبناء الإنترنت بآبائهم، مصدراً للمعلومات، وفقدوا الترابط 
الآثار السلبية لاستخدام الإنترنت على طلاب الجامعة

الأسري، والتصقوا بالحوار مع الغرباء لدرجة الثعور بالغربة على مستوى الأسرة الواحدة،

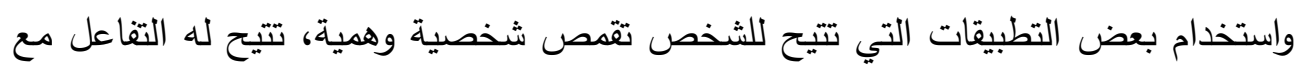
مجتمع وهمى وأصدقاء وهميين.

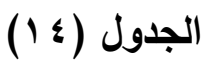

التكرار والنسب المئوية والدلالات الإحصائية الخاصة (بالآثار السلبية اجتماعياً للإنترنت)

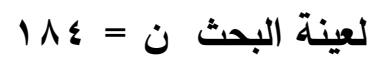

\begin{tabular}{|c|c|c|c|c|}
\hline \multirow{2}{*}{ الترتيب } & \multicolumn{2}{|c|}{ الالالات الإحصائية } & \multirow{2}{*}{ التصنيف } & \multirow{2}{*}{ المتغير } \\
\hline & النسبة\%\% & الت التكرار & & \\
\hline 1 & $\% 79.070$ & IYA & 1- العزلة الاجتماعية & \\
\hline r & $\%$ \% & 111 & الاجتماعية. & الآثار \\
\hline 0 & $\% \curlyvee \wedge . \wedge \cdot \varepsilon$ & or & 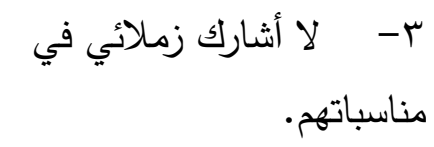 & السلبية \\
\hline 7 & $\% \backslash 7 . \wedge \leq \vee$ & r & ع ـ التمرد على العادات & ل للإنترنت \\
\hline$\varepsilon$ & $\% \leq r . r q 1$ & $\vee \wedge$ & 0- ق ملل من زيارة الأقارب. & \\
\hline r & $\% 00 . \varepsilon \Gamma \varepsilon$ & $1 \cdot r$ & الاجتماعية. & \\
\hline
\end{tabular}

يتضح من الجدول السابق أن أكثر الآثار السلبية اجتماعياً للإنترنت العزلة الاجتماعية، و يضعف العلاقات الاجتماعية، وعدم أداء الواجبات الاجتماعية لدى عينة

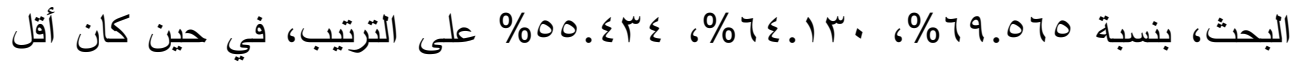


د/ فتحي جاب الله إدريس عبدالدايم

الآثار السلبية اجتماعياً للإنترنت التمرد على العادات والقيم الاجتماعية بأقل نسبة، وبلغت

$. \% 17 . \wedge \leqslant V$

وهذه النتائج تعطينا مؤشراً إلى أن الإفراط في استخدام الإنترنت تجعل الثاب يبتعد

عن والديه ويقضي ساعات طويلة أمام هذه الشبكة وتظهر عليه ما يعرف بإدمان الإنترنت، ومن مخاطر هذا الإدمان الانعزال وترك الحياة الاجتماعية، ونتيجة لقضاء ساعات طويلة أمام شبكة الإنترنت يقل الاختلاط بالناس، ويصبح منعزلاً ويتعود على هذا الانعزال الاجتماعي. حيث أن استخدام شبكة الإنترنت يقوم على طابع الفردية؛ فبدلاً من أن يقوم الفرد بالنشاط كالتسوق ومشاهدة البرامج الترفيهية مع أسرته أصبح يقوم به بمفرده على شبكة الإنترنت، مما يخشى معه من نشوء أجيال لا تجيد التعامل إلا مع الحاسب الآلي.

جدول رقم (10)

التكرار وإلنسب المئوية والدلالات الإحصائية الخاصة (بالآثار الصحية للإنترنت) لعينة

البحث ن = ع الت

\begin{tabular}{|c|c|c|c|c|}
\hline \multirow{2}{*}{ الترتيب } & \multicolumn{2}{|c|}{ الدلالات الإحصائية } & \multirow{2}{*}{ التصنيف } & \multirow{2}{*}{ المتغير } \\
\hline & النسبة\%\% & التكرار & & \\
\hline r & $\% \pi 1 . \leqslant 1 T$ & $11 \pi$ & آلام في الظهر والرقبة & \multirow{5}{*}{ لالإنثار } \\
\hline 1 & \%^ร.૫rq & 100 & قلل من ساعات النوم & \\
\hline 0 & \%rr.rAT & $\varepsilon 1$ & $\begin{array}{r}\text { آلام في مفاصل } \\
\text { الأصابع }\end{array}$ & \\
\hline r & \%or.VIV & $9 \vee$ & ضعف النظر & \\
\hline$\varepsilon$ & $\%$ \%т.790 & $T r$ & زيادة الوزن بسبب كثرة & \\
\hline
\end{tabular}

يتضح من الجدول السابق أن قلة ساعات النوم، وآلام في الظهر والرقبة، وضعف هُ

النظر أكثر الآثار السلبية للإنترنت على الصحة شيوعاً لاى عينة البحث، بنسبة

9As.r q

rvq

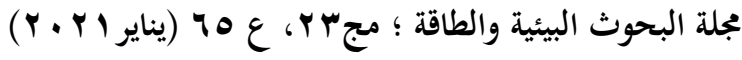


الآثار السلبية لاستخدام الإنترنت على طلاب الجامعة

للإنترنت على الصحة لدى عينة البحث آلام في مفاصل الأصابع بأقل نسبة، وبلغت \%rr.rAr

ومن هذه النتائج يلاحظ أن هناك آثاراً صحية لاستخدام الإنترنت، منها آلام

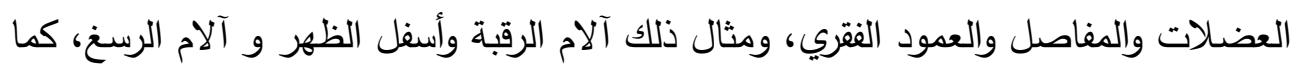
يمكن أن يؤدى إلى زيادة الوزن نتيجة لعدم الحركة مع تتاول الوجبات والمشروبات عالية

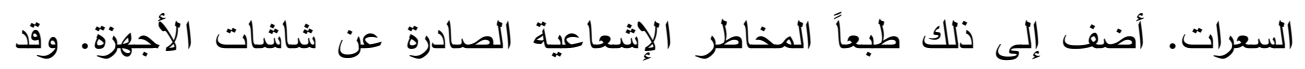
ترجع هذه النتائج إلى الوضع الخطأ للفرد في أثناء استخدامه للإنترنت، وميله برأسه للأمام موجهاً نظره تجاه الشاشة للتركيز مما يؤثر على نظره، حيث أن الأشخاص الذين يقرأون

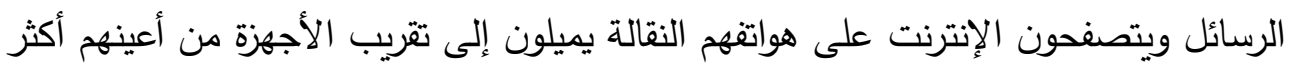
من الكتب والصحف، ما يجبر العين على العمل في شكل متعب أكثر من العادة، إضافة إلى أنه يقلل من ساعات النوم حسب رأي أكثر عينة البحث، ونظرًا لأهمية النوم بالنسبة

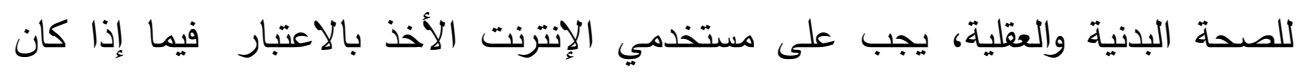

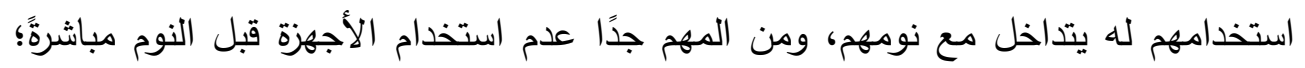
لأنها قد تتداخل مع النوم، وبشكل عام فأنه يسبب كثيراً من المشكلات الصحية سالفة الذكر .

$$
\text { الجدول (17) (19) }
$$

التكرار والنسب المئوية والدلالات الإحصائية الخاصة (بأثر الإنترنت على الثعائر الاينية)

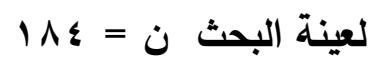

\begin{tabular}{|c|c|c|c|c|}
\hline الترتيب & \multicolumn{2}{|c|}{ الدلالات الإحصائية } & \multirow{2}{*}{ التصنيف } & \multirow{2}{*}{ المتغير } \\
\hline & النسبة\%\% & 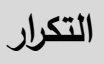 & & \\
\hline 1 & $\%$ \% . & iro & الفروض الدينية. & \multirow{3}{*}{ على الثرائر الإنترنت } \\
\hline r & $\% 0$ & $9 r$ & 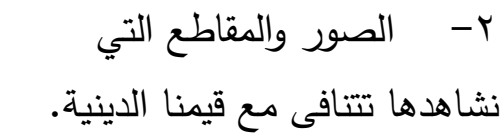 & \\
\hline r & $\%$ \%.ाए. & VY & r- يؤدي استخدام الإنترنت إلى & \\
\hline
\end{tabular}

rA.

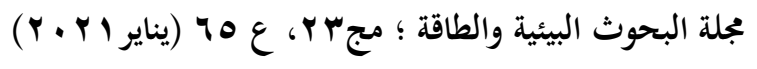


د/ فتحي جاب الله إدريس عبدالدايم

\begin{tabular}{|c|c|c|c|}
\hline & & & التأخر عن أداء الصلاة في وقتها. \\
\hline$\varepsilon$ & $\%$ & 71 & غ - ينشر البعض معلومات دينية \\
\hline
\end{tabular}

يتضح من الجدول السابق أن الإنترنت يشغلنا عن أداء الفروض الدينية والصور

التي نشاهدها تتنافى مع قيمنا الدينية، ويؤدي استخدام الإنترنت إلى التأخر عن أداء الصلاة الصناة

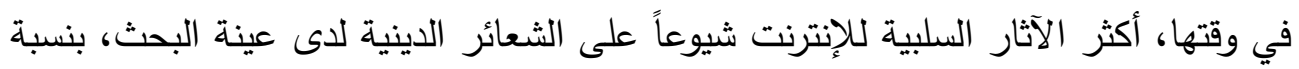

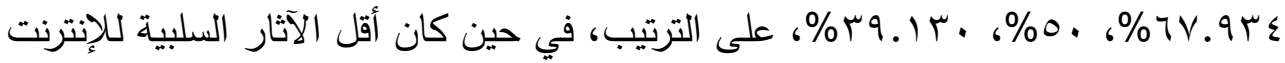
على الشعائر الدينية لدى عينة البحث أن ينشر البعض معلومات دينية غير صحيحة بأقل

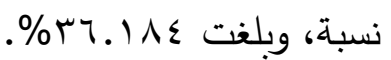
وقد ترجع هذه النتائج إلى أن الإنترنت إذا ما أسيء استغلاله يؤدى إلى ضياع وقت الفراغ، مما يشغل الفرد عن الفروض الدينية، ويدفعه إلى مشاهدة الصور التي تتنافى لإلى مع القيم الدينية.

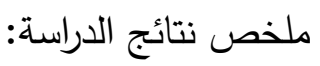
1- أكثر عينة البحث تستخدم الانترنت في المنزل و عند اصدقائهم. ץ- العدد الاكبر من عينة البحث يستخدمون الانترنت بمفردهم. r- اكثر مواقع التواصل الاجتماعي التي تستخدمها عينة البحث هي الفيس بوك. ع- غالبية عينة البحث يستخدمون الانترنت مساءً.

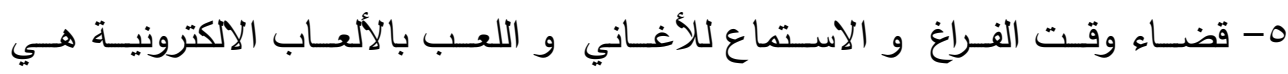
أهم دوافع التسلية والترفيه لاستخدام الانترنت لدى عينة البحث.

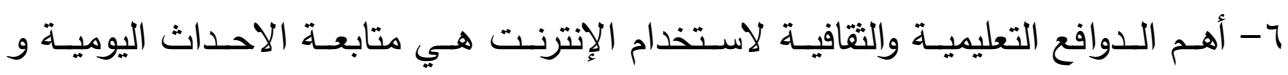
التعرف على اخبار المجتمع و زيادة الثقافة.

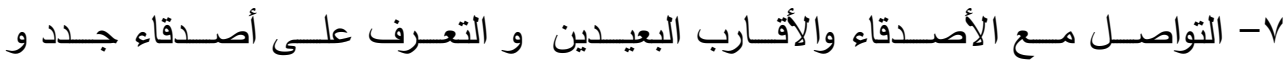
إثبات الذات هي أهم الدوافع الاجتماعية لاستخدام الانترنت لدى عينة البحث. 


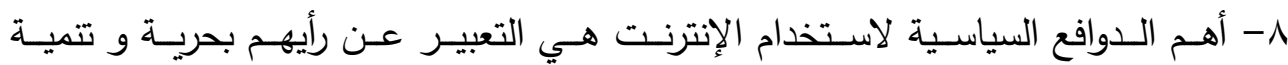
ثقافتهم السياسية و مناقثة القضايا السياسية

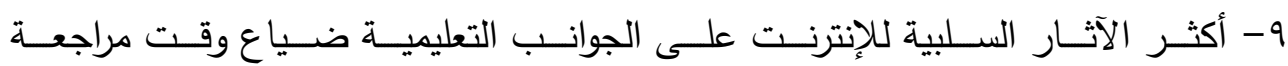

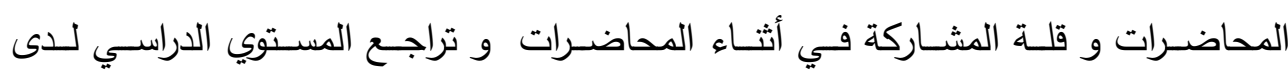
عينة.

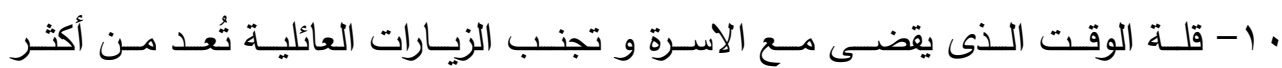
الآثار السلبية للإنترنت على العلاقات الأسرية.

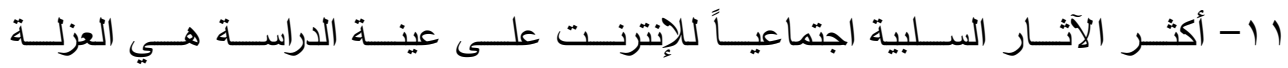
الاجتماعية أو ضعف العلاقات الاجتماعية.

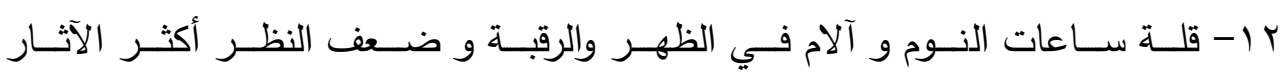
السلبية للإنترنت على الصحة لاى عينة الدراسة.

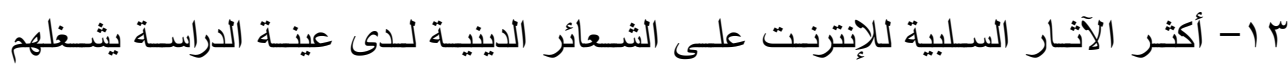

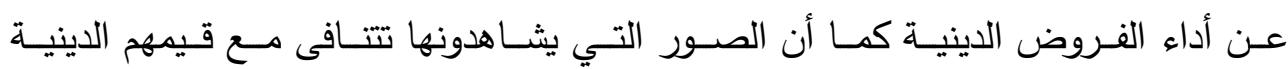
بالإضافة إلى التأخر عن أداء الصلاة في وقتها. التوصيات:

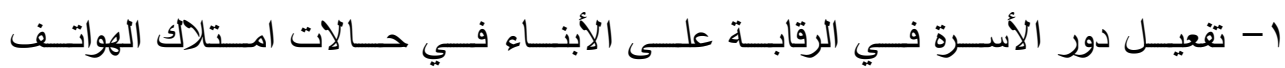
المحمولـة، خاصــة في فتـرة المراهفـة، وتـوجيههم الوجهـة الصــيحة في أثتـاء اسـتهلاكك واستقبال ما تتتجه هذه الوسائل. r- إيجـاد نظـام اجتمـاعي عـام لشــل وقـت الفــاغ بالنسـبة للشـباب لا سـيما في فتـرات

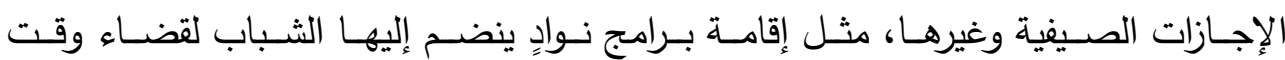
الفراغ.

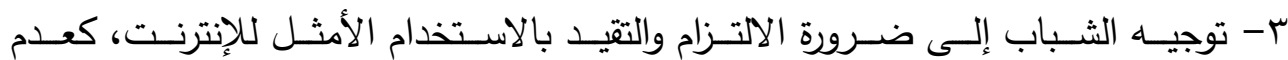
الدخول للمواقع المحظورة. 
د/ فتحي جاب الله إدريس عبدالدايم

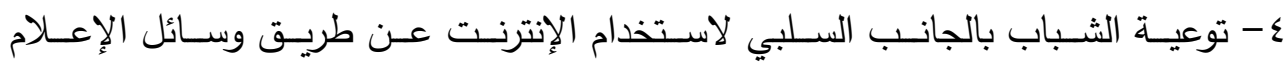
المختلفة؛ المرئية المسموعة منها والمقروءة.

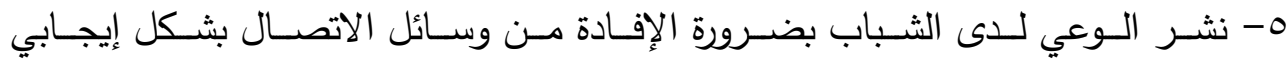
عن طريق المحاضرات والمنشورات عن طريق الإنترنت نفسه.

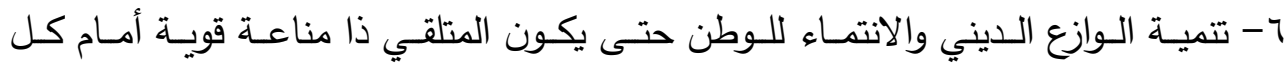
ما من شأنه أن يجرده من انتمائه وأصوله، أو يخش الـاء في عقيدته ودينه.

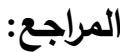

1- أمين سعيد عبدالغني، وسائل الاعلام الجديدة والموجة الرقمية الثانية، م . . ب.

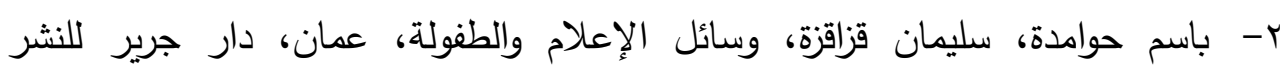

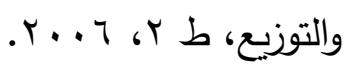

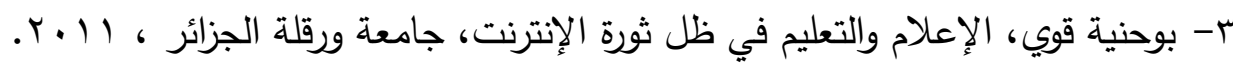

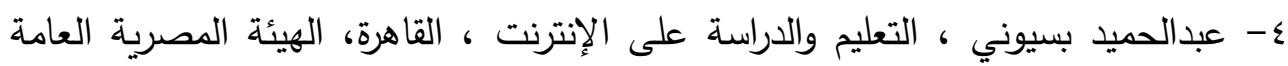

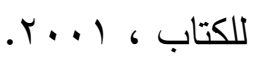
ه- عبدالله محم عبدالرحمن، سوسيولوجيا الاتصال والإعلام، الإنكندرية، دار المعرفة

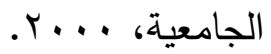

צ- علي خليل شقرة، الإعلام الجديد شبكات التواصل الاجتماعي، عمان، دار أسامة

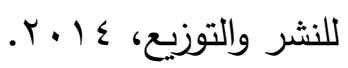

V - مؤمن أحمد، أمن الإنترنت.. المخاطر والتحديات، دولة الأمارات العربية المتحدة، مكتب

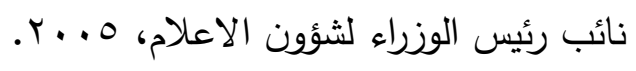

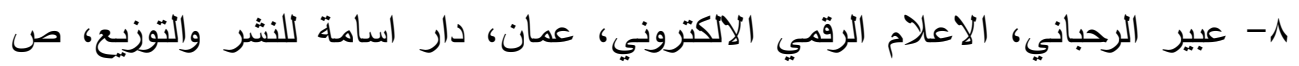
$.1 T r$ 9- تحمد النوبي تحمد، إدمان الإنترنت في عصر العولمة، عمان، دار صفاء للنشر والتوزيع، .r. .

rAr

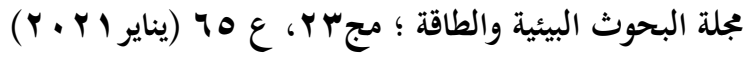


• ا- يامين حمد بودهان، الشباب والإنترنت، عمان، دار مجدلاوي للنشر والتوزيع، .$r .1 \varepsilon$

11- أحمد بكر قنيطة، الآثار السلبية لاستخدام الإنترنت من وجهة نظر طلبة الجامعة الاسلامية بغزة ودور التربية الاسلامية في علاجها، غزة، الجامعة الإسلامية، كلية

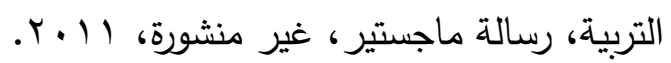

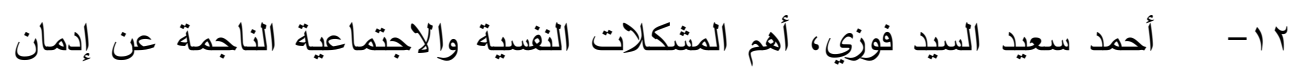
المراهقين للإنترنت، القاهرة، جامعة عين شمس، معهد الدراسات العليا للطفولة، رسالة

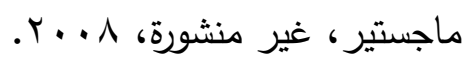

rا - إلهام بنت فريج العوضي، أثر استخدام الانترنت على العلاقات الأسرية بين أفراد الاسرة السعودية في محافظة جدة، الإدارة العامة لكليات البنات بجدة، كلية التربية،

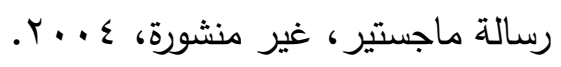

ـ ا- أمل الزيدي، إدمان الإنترنت وعلاقته بالتواصل الاجتماعي والتحصيل الدراسي

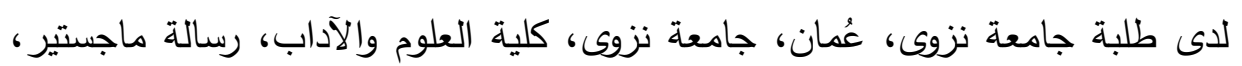

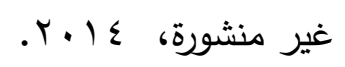

10- حنان بنت شعشوع الثهري، أثر استخدام شبكات التواصل الإلكتروني على العلاقات الاجتماعية " الفيس بوك وتويتر نموذجا"، جدة، جامعة الملك عبدالعزيز، كلية

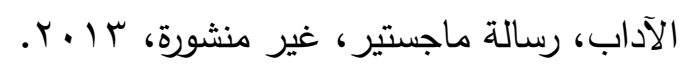

17- خالد محم السيد حسانين، استخدام المدخل المعرفي السلوكي من منظور خدمة الجماعة وتعديل اتجاهات الثباب الجامعي نحو استخدام شبكة الإنترنت، القاهرة،

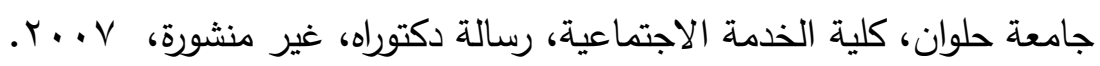
VI ا مامية زكي يوسف، شبكة الإنترنت وآثارها على الثباب المصري، دراسة سوسيولوجية، القاهرة، جامعة عين شمس، كلية الآداب، رسالة ماجستير، غير منشورة،

. . . A

YA $\varepsilon$

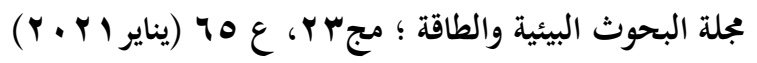


د/ فتحي جاب الله إدريس عبدالدايم

11- سلطان عائض العصيمي، ادمان الإنترنت وعلاقته بالتوافق النفسي والاجتماعي لدى طلاب المرحلة الثانوية بمدينة الرياض، الرياض، جامعة نايف العربية للعلوم الامنية، كلية الدراسات العليا، رسالة ماجستير، غير منشورة، • • ب. 9 19- سماح رمزي، سوء استخدام الإنترنت وعلاقته ببعض متغيرات الشخصية، القاهرة، جامعة القاهرة، معهد الدراسات التربوية، رسالة ماجستير، غير منشورة، V... Y.

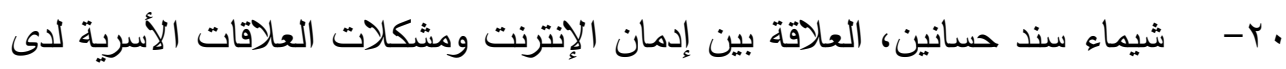
طالبات المرحلة الثانوية، القاهرة، جامعة حلوان ، كلية الخدمة الاجتماعية، رسالة

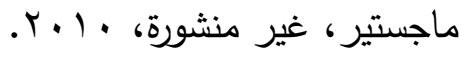

اب- ناجية مصطفى عمارة، تأثير استخدام الإنترنت على الشباب الجامعي، المنصورة،

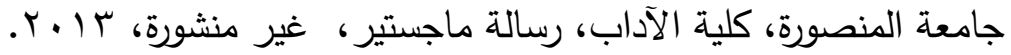
r r- نعمة محمد السيد، الاستخدام السلبي للإنترنت وأثثه في التفكك الأسري، جامعة

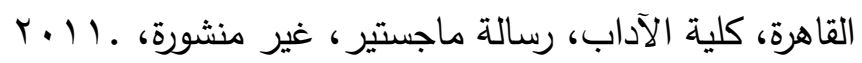
بr- وسام عزت محهد، إدمان الإنترنت وبعض المشكلات الأكثر شيوعاً لدى المراهقين من من

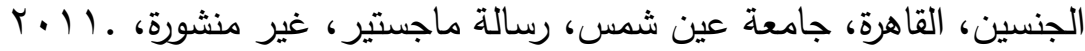
ع ץ- جهاد علاء الدين، النتائج السلبية لاستخدام الإنترنت: دور الاستخدام الإشكالي للإنترنت والوحدة والاكتئاب، الأردن، المجلة الأردنية في العلوم التربوية، العدد الثالث،

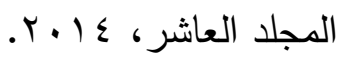

هץ- منال عبده ححم منصور ، التأثيرات المترتبة على استخدام الشباب الجامعي لموقع الفيس بوك، القاهرة، جامعة القاهرة، كلية الإعلام، المجلة المصرية لبحوث الإعلام،

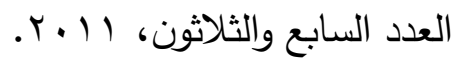

Tr. صالح سليمان عبدالعظيم، الابعاد والتأثيرات الاجتماعية المرتبطة باستخدام الإنترنت على الأسرة العربية، القاهرة، جامعة عين شمس ، كلية الآداب، بحث منشور في

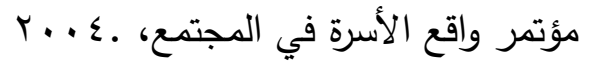


V V. تححد السيد ابوالمجد عامر، الآثار السلبية لإدمان الإنترنت ودور الخدمة الاجتماعية في التخفيف من حدتها، القاهرة، جامعة حلوان، كلية الخدمة الاجتماعية، بحث منشور في المؤتمر الحادي والعشرين للخدمة الاجتماعية، المجلد الحادي عشر ، م . . ؟. 1 ץ. حمح محمد حسان إبراهيم، الأنشطة الجماعية والتخفيف من الآثار السلبية لسوء استخدام الانترنت لدى الطلائع، الفيوم، جامعة الفيوم، كلية الخدمة الاجتماعية، بحث منشور

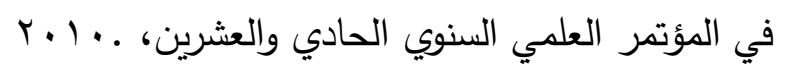

q - مددوح محم دسوقي، سوء استخدام الإنترنت وعلاقته بمشكلات طلاب الجامعة، القاهرة، جامعة حلوان، كلية الخدمة الاجتماعية، بحث منشور في المؤتمر الثاني والعشرين

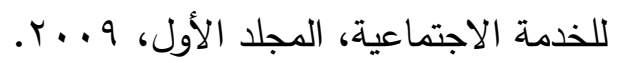

132- Aida Abdulahi, A Study on the Negative Effects of Social Networking Sites Such as Facebook among Asia Pacific, International Journal of Business and Social Science, University of Technology Malaysia, 2014.

133- Cenk Akbiyik, Effects of Social Networks on Social Life of Undergraduate Students, Middle Eastern \& African Journal of Educational Research, Issue 6, Erciyes University Faculty of Education, Kayseri Turkey, 2013.

137.Christos C. Frangos, Internet Addiction among Greek University Students, International Journal of Economic Sciences and Applied Research, University College London, London, UK, 2009.

138.Sebastián Valenzuela, The Effect of Social Network Sites on College Students, University of Texas at Austin, International Symposium on Online Journalism, 2008.

140.Chien Chou, Internet addiction, usage, grati cation, and pleasure experience: the Taiwan college students' case, National Chiao Tung University,Taiwan,2000. . 